Article

\title{
Torrefaction as a Pretreatment Technology for Chlorine Elimination from Biomass: A Case Study Using Eucalyptus globulus Labill
}

\author{
Letícia C. R. Sá ${ }^{1}$, Liliana M. E. F. Loureiro ${ }^{1}$, Leonel J. R. Nunes ${ }^{2,3, * \mathbb{C}}$ and \\ Adélio M. M. Mendes ${ }^{4}(\mathbb{D})$ \\ 1 YGE-Yser Green Energy SA, Área de Acolhimento Empresarial de Úl/Loureiro, Lote 17, \\ 3720-075 Loureiro OAZ, Portugal; leticia.reis@ygenergia.com (L.C.R.S.); \\ liliana.loureiro@ygenergia.com (L.M.E.F.L.) \\ 2 proMetheus-Unidade de Investigação em Materiais, Energia e Ambiente para a Sustentabilidade, \\ Escola Superior Agrária, Instituto Politécnico de Viana do Castelo, Rua da Escola Industrial e Comercial de \\ Nun'Alvares, 4900-347 Viana do Castelo, Portugal \\ 3 GOVCOPP — Unidade de Investigação em Governança, Competitividade e Políticas Públicas, \\ DEGEIT_-Departamento de Economia, Gestão, Engenharia Industrial e Turismo, Universidade de Aveiro, \\ Campus Universitário de Santiago, 3810-193 Aveiro, Portugal \\ 4 LEPAE—Laboratório de Engenharia de Processos, Ambiente e Energia, FEUP—Faculdade de Engenharia da \\ Universidade do Porto, Rua Roberto Frias, 4200-465 Porto, Portugal; mendes@fe.up.pt \\ * Correspondence: leonelnunes@esa.ipvc.pt; Tel.: +351-258-909-740
}

Received: 10 April 2020; Accepted: 29 April 2020; Published: 1 May 2020 updates

\begin{abstract}
The recognition of the effects of fossil fuel consumption resulted in several agreements, legislation, and projects focusing on the minimization of impacts caused. Biomass is a versatile energy source. Eucalyptus is a fast-growing crop, mainly used by the pulp and paper industry. Torrefaction is a thermochemical conversion process that can improve biomass fuel properties, enabling its use in the energy sector. However, correct management of biomass is crucial for the sustainability of this process. Torrefaction can also be used to eliminate some elements that can hinder subsequent conversion processes. One example is chlorine, which, during combustion or gasification processes, can form hydrochloric acid that leads to corrosion of metal surfaces. In this context, this research aimed to determine the temperature at which chlorine is eliminated during torrefaction process. For this purpose, several tests were performed at different temperatures and residence times. All samples were analyzed before and after the process, and were characterized by proximate and elemental analysis, calorimetry, and chlorine titration. The analysis showed that, even for the lowest torrefaction temperature used, chlorine content was already below the detection value, showing that, even at lower temperatures, thermal treatment is an efficient technique for the elimination of chlorine from biomass.
\end{abstract}

Keywords: eucalyptus; biomass energy; torrefaction; chlorine content

\section{Introduction}

Humans have used energy derived from fossil fuels for a long time without thinking of the consequences, and it is now increasingly clear that actions must be taken to rectify the situation [1]. Ever growing concentration of greenhouse gases (GHGs) in the atmosphere, the shortage of fossil fuel reserves, and the rise in temperature are some of the main concerns presently faced by mankind, and with each passing day new research provides different pathways to address these challenges, or at least part of them [2]. Biomass is only one of the options, but it has an enormous potential [3]. 
Biomass can be converted into usable forms of energy, such as heat and electricity [4]. It can be obtained from several sources, including waste from forestry and agricultural operations, or from other industries, such as pulp and paper, or textile industries [5]. This energy source has many advantages if managed correctly. It is highly available, produces low levels of GHGs during its conversion, and can result in many different energy forms, following actual energy grid needs [6]. However, wasteful consumption without replacement, lack of treatment for secondary gaseous products, and even the high costs of transportation make the use of biomass oftentimes unfeasible and environmentally unfriendly [7].

In its natural form, the chemical and physical properties of biomass can hinder its use in some energy applications [8]. Its low bulk density and heating value, along with its high moisture content and poor grindability, make biomass a worse fuel than coal [9]. However, it is possible to pretreat biomass before other conversion processes [10]. In the thermal energy sector, torrefied biomass can have an important role in combustion applications, since it can be fired directly, either alone (as the only source of fuel) or along with a primary fuel (co-firing) [11].

Torrefaction is a thermochemical conversion process that occurs in the temperature range of $220-320{ }^{\circ} \mathrm{C}$, with oxygen shortage and under atmospheric pressure conditions [12]. It is based on the molecular disintegration of hemicellulose, with small alterations in the structures of cellulose and lignin [13]. As a result, the ability of biomass to acquire moisture and to rot decreases, simplifying storage cautions [14]. Furthermore, during the process, there is a partial devolatilization that leads to a decrease in mass, even though the initial energy content is mostly preserved, which means higher energy density and lower transportation costs [15].

In Portugal, the potential of the available forest biomass is $2.2 \times 10^{6}$ tons per year, which corresponds to approximately $20 \%$ of the country needs [16]. However, forest biomass is the main raw material for several processes, particularly for the pulp and paper industry, which makes it a highly competitive market [17]. For that reason, it is necessary to find alternatives for the most required types of forest biomass in order to minimize production costs. Eucalyptus genus is native to Oceania, where it is the dominant genus of flora. The genus includes more than 700 species, almost all originated in Australia, with only a small number of species belonging to neighboring territories of New Guinea and Indonesia, and one more species (the most northern) in the southern Philippines. The genus acquired great importance due to its utilization as fiber raw material and for biomass production [18]. It is also known for its high flammability and fire survivability, which may cause problems in dry-climate locations [19]. The pulp and paper industry in Portugal use mainly older eucalyptus trees with diameters larger than $10 \mathrm{~cm}$. The possibility of using the remaining and disposed smaller eucalyptus available for the production of torrefied biomass could guarantee lower production costs and reduce the risk of wild fires [20].

The purpose of this research was to encourage the incorporation of eucalyptus trees with diameters smaller than $10 \mathrm{~cm}$ into the biomass energy supply chain. This article presents the results obtained from six samples of eucalyptus trees, ranging from 2 to $9 \mathrm{~cm}$ in diameter. The main focus was the analyses of the amount of chlorine present in the biomass that could later damage the equipment during thermal reactions. A set of analyses was performed for characterizing raw biomass. After torrefaction, a new set of analysis took place to determine the remaining amount of chlorine. Torrefaction occurred at three different temperatures and residence times, with the objective to determine at which temperature chlorine would disappear and which combination would guarantee the best results.

\section{State-Of-The-Art}

\subsection{Biomass}

IUPAC (International Union of Pure and Applied Chemistry) defines biomass as a material produced by the growth of microorganisms, plants, or animals, which can be used to produce energy [21]. In 2017, total energy production worldwide was 14 Mtoe, being biomass responsible for 
$10 \%$ of that value [22]. This source is extremely versatile since it is possible to generate power and heat through direct burning, or converted into several different forms, e.g., bio-oil or syngas [23].

Biomass originates from the reaction of $\mathrm{CO}_{2}$, water, and sunlight, via photosynthesis, to produce carbohydrates (or sugars) [24]. During photosynthesis, solar energy is stored in chemical bonds of the structural components of biomass. Due to human activity, especially fossil-fuel burning, atmospheric $\mathrm{CO}_{2}$ concentration increased. However, not all stays there, since part of it is used for photosynthesis, ending up in several types of biomatter. Classification of biomass depends on the field, purpose, and application [25].

Lignocellulosic biomass consists of an amorphous matrix that surrounds cellulose fibers, and acts as a natural barrier, making the structure of the biomass more rigid and less reactive [26]. Some key components of biomass are cellulose, hemicelluloses, lignin, starch, and proteins, although trees mainly consist of cellulose, hemicelluloses, and lignin [27]. Cellulose is an organic compound, with the formula $\left(\mathrm{C}_{6} \mathrm{H}_{10} \mathrm{O}_{5}\right)_{n}$, derived from D-glucose units linked uniformly through $\beta$-glucosidic bonds. Many properties of cellulose depend on its chain length or degree of polymerization, indicated by $\mathrm{n}$, which is the number of glucose units that make up one polymer molecule, which can range from several thousand to several tens of thousands. It consists of crystalline and amorphous structures [28]. Hemicelluloses are a heterogeneous group of polysaccharides located in plant cell walls that have $\beta-(1 \rightarrow 4)$-linked backbones with an equatorial configuration, and the average molecular formula is $\left(\mathrm{C}_{5} \mathrm{H}_{8} \mathrm{O}_{4}\right)_{\mathrm{n}}$. Its principal role is the contribution to the cell wall strength. Since the degree of polymerization, $n$, is between 50 and 200, they are easier to break down than cellulose and generally soluble in alkaline solutions [29]. Lignin is a constituent of all vascular plants, is the second most common organic substance on Earth, and influences the transport of liquids in the plant, making it possible for the plant to grow and compete for sunlight. Lignin is a three-dimensional polymer composed of a structure based on phenylpropane and its derivates. Its molecular structure is incredibly complex and hard to decompose. For that reason, its function is thought to confer mechanical strength and protection [30]. Chemical composition of lignocellulosic biomass varies among species, but it generally contains $10-25 \%$ lignin, which are non-sugar type molecules that act as a glue, uniting fibers, and $75-90 \%$ carbohydrates or sugars, which are linked together to form long chains or polymers and a small amount of ash and extractives [31].

Apart from the components previously discussed, there are a few other components that need special attention concerning biomass and conversion processes leading its valorization. Moisture is one of the main factors to consider. Wetter biomass has a lower calorific value, limiting the amount of energy obtained from it. For example, moisture content can vary significantly from as low as $3 \%$ in paper to $98 \%$ in sludge [32]. Ash is the non-combustible portion of the raw biomass. There are two types of ash present in biomass, the part formed by salts that are chemically bonded to the carbon structure, and the part composed by mineral soil particles gathered during growth or harvest and transport. High ash content leads to fouling and slagging problems, especially if the ash is high in alkali metals [33].

Carbon content is another crucial aspect to consider since heating value depends on the ratio of elements, especially carbon, in the biomass. A higher carbon content in raw biomass means a higher heating value. Coal consists of at least $60 \%$ carbon, while raw biomass only contains around $45 \%$ [5]. Hydrogen is the third major constituent of biomass, comprising typically $5-6 \%$ dry matter [34]. Its impact is similar to carbon content, where higher percentages of hydrogen also lead to higher heating values [35]. Nitrogen content varies from $0.2 \%$ to $1 \%$, and it is directly related to $\mathrm{NO}_{\mathrm{x}}$ emissions. For that reason, the lower is the amount present in the biomass, the better [36]. Sulfur content is relatively low, especially when compared to coal, but it can have negative impacts on the environment. Although this value is normally below $0.2 \%$, its presence leads to the formation of $\mathrm{SO}_{\mathrm{x}}$, which are partly responsible for particulate matter pollution and acid rain [5].

Some nutrients, such as $\mathrm{Ca}, \mathrm{Mg}, \mathrm{Na}, \mathrm{K}$, and $\mathrm{P}$, are fundamental to plants and can be obtained from air or soil [37]. However, during biomass collection, these nutrients are removed from the soil, which 
can impair the possibility of new plants growing in that location. For that reason, it is crucial to find a way to recycle those nutrients back [38]. A high chlorine concentration can cause severe impacts to the process. High-temperature chlorine corrosion of superheaters is the worst of them since it leads to higher maintenance costs [39].

\subsection{Biomass Thermochemical Conversion}

\subsubsection{Torrefaction Process}

Biomass conversion into an enriched product involves different biomass sources and varieties, and the determination of the best conversion process for each situation depends on many factors, such as the type and quantity of biomass, the desired product, environmental standards, economic conditions, and available infrastructure [40]. The most common processes used today are of thermochemical and/or biological nature, as shown in Figure 1.

Combustion is the primary process adopted worldwide to convert biomass into heat, mechanical energy, or electricity, and it is also the oldest one [41]. During the process, flammable materials are burned in the presence of air, or oxygen, to release heat [42]. To be feasible, this process requires biomass with a moisture content lower than 50\% [43]. Combining fossil fuels, such as coal or natural gas, with biomass is known as co-firing, and it has several advantages since it reduces the amount of GHGs emission and, depending on the ratio used, loses little efficiency [44].

Gasification is the partial oxidation of biomass above $800{ }^{\circ} \mathrm{C}$ with a controlled amount of oxygen [45]. Molecules break down to produce syngas, which is a mixture of $\mathrm{CO}$ and $\mathrm{H}_{2}$ that can be used for many applications [46]. Its higher efficiency makes it more desirable than direct combustion, and there are many methods available, which are classified according to combinations of conditional factors, such as pressure, temperature, gasifying agent, heating rate and gasifier type [47].

Pyrolysis is a thermochemical process where biomass heats up to approximately $500{ }^{\circ} \mathrm{C}$ in a scarce or low-oxygen atmosphere, preventing total combustion but still causing changes in the chemistry of the biomass [48]. Pyrolysis produces a hydrocarbon-rich gas mixture, an oil-like liquid, and a carbon-rich solid residue, with proportions depending on process parameters [49]. Although the expectation was to have low dioxin emission, high power generation efficiency, and the recycling of molten slag, recent studies have shown that the process requires high consumption of auxiliary energy and that slag recycling rate is low and not worth the cost [50].

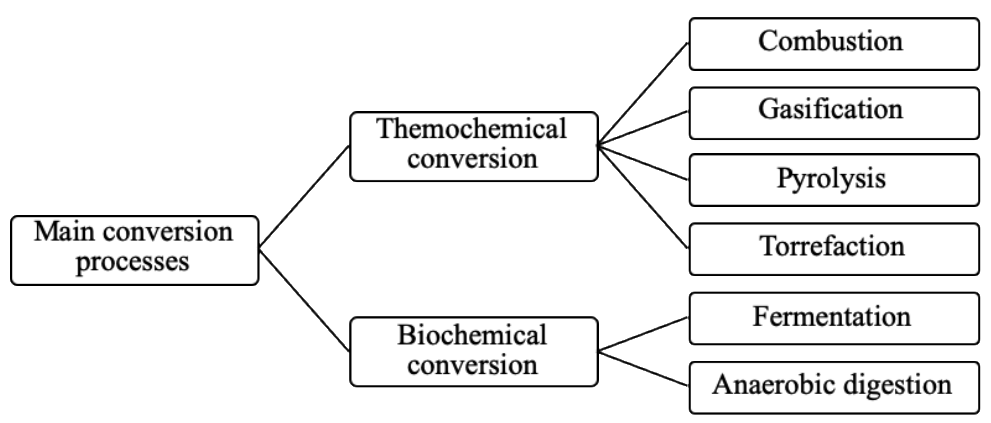

Figure 1. Main biomass conversion technologies available (adapted from [51]).

Torrefaction is a conversion process where biomass is heated in the range from 220 to $320{ }^{\circ} \mathrm{C}$, at atmospheric pressure and in the absence or scarcity of oxygen [52]. During the process, hemicellulose is decomposed, while lignin and cellulose remain practically the same. It can be used as a pretreatment since it improves several properties of raw biomass, making it a better fuel for other process, such as combustion or gasification [53].

Fermentation is a biological process that happens at room temperature and pressure. During the reaction, microorganisms convert organic material into simpler compounds in anaerobic condition. It 
is possible to produce ethanol from biomass-containing sugars, starch, or cellulose, but both starch and cellulose require additional processing even though they are usually cheaper than sugar-based sources [54].

Anaerobic digestion is the degradation of the carbonaceous matter in organic compounds through bacterial action in the absence of oxygen. The decay of sewage and animal waste generates biogas, a mixture of methane and carbon dioxide, with small quantities of other gases [55].

During torrefaction, biomass is decomposed at moderate temperatures in the absence of oxygen and at atmospheric pressure. The lower temperature limit is related to the onset of decomposition of hemicelluloses, and the second limit is related to the onset of decomposition of cellulose [56]. This temperature range guarantees that the main target of the decomposition, in the case of lignocellulosic biomass, is hemicellulose, even though both lignin and cellulose may also suffer some decomposition [57]. Several studies have proven the benefits of the biomass torrefaction process [53,58-60]. As a result, it is possible to obtain a substantial increase in the performance of biomass during co-combustion and gasification processes [61]. Apart from the improvements mentioned above, there are many others: lower grindability and moisture, higher heating value and hydrophobicity, and more homogeneous properties give torrefied biomass a more significant appeal when compared to raw biomass [62]. These new characteristics simplify storage, reduce transportation costs and energy consumption, and optimize energy production.

The torrefaction process can be divided into five main stages, which guarantee the optimization of torrefaction by taking into account changes that occur throughout the process. Bergman [63] came up with the following definitions that are now the basis for defining these temperature-time stages:

- Initial heating: The temperature of the biomass starts to increase and moisture starts to evaporate in the end.

- $\quad$ Pre-drying: It occurs at approximately $100{ }^{\circ} \mathrm{C}$ and, during this stage, free water present in biomass evaporates at a constant rate.

- Post-drying and intermediate heating: The temperature of the biomass increases to $200{ }^{\circ} \mathrm{C}$. At this stage, biomass releases water present in its chemical bonds, practically eliminating all the moisture. Due to the evaporation of light organic compounds, some mass loss can occur.

- Torrefaction: This is the stage where the biomass is torrefied. It happens during the time in which the temperature is superior to $200{ }^{\circ} \mathrm{C}$, or $220^{\circ} \mathrm{C}$ as previously mentioned, and consists of a heating period, a constant temperature period, and a cooling period. Mass loss starts during the first and stops after the latter. The maximum constant temperature reached is known as the torrefaction temperature $\left(\mathrm{T}_{\mathrm{Tor}}\right)$.

- $\quad$ Solids cooling: The torrefied biomass cools further until it reaches room temperature.

\subsubsection{Torrefaction Parameters}

The following parameters have been proven to affect torrefaction process and final products [64]:

- $\quad$ Temperature and residence time: They are crucial to understand how the exposure of biomass to high temperatures affects its structure since it generally results in mass loss. The temperature attained and its duration influence the degree of thermal degradation. Regarding residence time, previous studies commented the importance of replacing this term with reaction time since the former mainly influences the degradation of hemicellulose, while the latter affects the cellulose mass loss $[65,66]$. As mentioned, the torrefaction process has several heating stages, even before torrefaction starts. Therefore, residence time does not represent biomass exposure to torrefaction. When comparing the effects of temperature and residence time on the characteristics of the final product, it is important to mention that both are connected and dependent on each other, even though temperature has a more significant influence since it defines the kinetics of the reaction.

- Heating rate: The heating rate $\left({ }^{\circ} \mathrm{C} / \mathrm{min}\right)$ chosen during torrefaction affects solid, liquid, and gaseous portions in the final product, since it influences secondary degradation reactions. The use 
of high heating rates reduces parallel reactions, which impacts the distribution of the products. A recent study suggested that the effects of heat and mass transfer in the particles decrease by increasing the heating rate [67].

- Atmosphere composition: The torrefaction process can be affected by the gas flow used during the process due to the secondary interactions between the gases. Carbon monoxide is the main gas released in the process, occurring through a secondary reaction as the temperature increases. Furthermore, the longer is the residence time, the lower is the $\mathrm{CO}_{2} / \mathrm{CO}$ ratio. There are no substantial changes in biomass reactivity or in the solid reaction products depending on the presence of $\mathrm{O}_{2}$ in the atmosphere.

- Reactor type: Besides being a relatively new technology, there are several reactors available in the market $[68,69]$. Reactor design is the main difference between the technologies, each one with its heat transfer method and mixing pattern, determining product quality. The most commonly used technologies are the rotatory drum kiln, which is indirectly heated (through the reactor wall) and the rotary drum reactor, which is directly heated [70].

\subsubsection{Torrefied Biomass Properties}

As mentioned above, the purpose of torrefaction is to transform natural biomass into a product with better fuel characteristics by altering some of its properties. Although this process influences several biomass attributes, it presents most of its alterations in the following features [71]:

- Moisture content: Before torrefaction process, moisture content in raw biomass ranges from $10 \%$ to $50 \%$, but, by the end, it reaches $1-3 \%$ due to the high temperatures obtained during the process. This reduction contributes to many improvements, such as a lower transportation cost since there is no unwanted water in the product, simplified storage, transportation given by its new hydrophobicity, and better performance during the subsequent conversion process due to a higher heating value.

- Energy and bulk density: The torrefaction process results in loss of mass in different states, which leads to an increase in biomass porosity. As a result, both volumetric and bulk densities decrease, even though several studies have shown a substantial increase of more than $50 \%$ in energy density [72].

- Grindability: Biomass is naturally fibrous and tenacious. During torrefaction, structural changes decrease the length of the fibers, making it weaker. This modification favors the utilization of biomass alongside coal in processes such as co-firing and co-gasification, since solid fuel is now easily ground. Apart from that, energy consumption during grinding decreases significantly, with some studies observing reductions of 70-90\% [73].

- Heating value: The torrefaction process increases the carbon content, while the oxygen and hydrogen content of the biomass decrease with increasing temperature. The amount of carbon lost during the process is lower than the loss of other components, which leads to a higher heating value when compared to raw biomass. This increase results in better combustion characteristics and approaches properties of torrefied biomass to those of coal.

As mentioned above, the purpose of this study was to determine the temperature at which chlorine elimination occurs during torrefaction. Therefore, the equipment used for torrefaction is not particularly relevant in this case. The choice of a reactor did not follow the conventional path, and the decision was to use a laboratory-scale high-temperature furnace, or ceramic muffle, as proposed by Ribeiro et al. [74], and already followed by other researchers in recently published works [75]. The generation of heat occurs through electrical resistance spread across the interior of the furnace, making it possible to reach the different heating stages needed in the process, such as a conventional reactor. This methodology was proven to be similar to other technologies available, and for research purposes it can be cheaper and more straightforward than the alternatives [74]. 


\subsection{Soil and Nutrient Depletion}

Biomass contains several macro- and micronutrients that are absorbed from air or soil, even though the proportions of each may vary among different species, ages, and locations [76]. There are 17 indispensable elements and substances responsible for the completion of the normal lifecycle of a plant. However, those are not always beneficial. When in excess, some of them can lead to soil, water, and air contamination, and even to death of the plant [77].

During their growth, trees accumulate heavy metals of anthropogenic origin, and these metals tend to accumulate in the ashes after the conversion processes, along with the nutrients [78]. The problem here is that, generally, ashes are returned to soil so that they can replace previously extracted nutrients, and heavy metals hinder recirculation of these nutrients, maximizing negative environmental impacts. The presence of heavy metals can contaminate soil and water, which can become a severe environmental problem. Therefore, the application of a separation technique could be extremely favorable [79].

\subsection{Forest Typology of Mainland Portugal}

In 2010, Portugal had a forest area that represented $35.4 \%$ of its territory. Since 1995, there was a reduction of almost $5 \%$ in the national forest area, which can be explained by an increase in urban area. However, this trend shifted in 2015 , with an increment of 59,000 ha (1.9\%), when compared to the previous assessment [80]. The 6th National Forest Inventory (IFN6) also concluded that, in 2005 and 2015, Portugal had the same amount of wood in growth $\left(172 \mathrm{Mm}^{3}\right)$. These data prove that forest production has been sustainable during this period and that it can remain sustainable if a balance among forest growth, logging, and losses from fire or pests prevails. The following four broad groups, or forest formations, make up the Portuguese mainland forest: pine forests, evergreen broadleaf, deciduous broadleaf, and industrial broadleaf forest [80,81].

- Pine forests are the second largest forest formation, but had a more considerable reduction in the occupied area.

- $\quad$ Evergreen broadleaves are cork oak and holm oak and represent about $1 / 3$ of the forest.

- Deciduous hardwoods composed of oaks, chestnut trees, and others are the least representative forest formation concerning the occupied area.

- Industrial broadleaf forests are composed by eucalyptus, which showed an increment in occupied area over the last 50 years, representing about $26 \%$ of the mainland forest.

Eucalyptus is distributed in Portugal mainly in the north and center regions, with predominance for the lowest quotas and in areas closer to the coast. However, some areas of the interior of the country have also extensive plantations of eucalyptus, mainly next to the large water courses, where large factories for the production of pulp have also been installed.

\subsection{Eucalyptus}

Eucalyptus globulus Labill., shown in Figure 2 (left), belongs to the Myrtaceae family and is originally from Australia [82]. In Portugal, E. globulus was introduced in the 19th century [19]. This species combines fast growth with high productivity, which makes it appealing for forest producers [83]. E. globulus has thick leaves, Figure 2 (right), which simplifies the light capture. Moreover, its form allows it to avoid stress caused by excessive light and to cool down through perspiration with air movement. All these factors, coupled with good biochemical defense against high temperatures, optimize photosynthesis during the entire year [83]. Despite that, eucalyptus is an exotic species that may present invasive behavior if not controlled and properly managed. Its advantage against others can lead to drastic consequences to the biodiversity in Portuguese forests, and its high flammability is a dangerous disadvantage, especially during dry season. At this moment, pulp and paper industry are 
the primary eucalyptus consumer in Portugal. However, there is still potential for the energy sector to explore this species and to minimize its adverse impacts on the Portuguese forest.
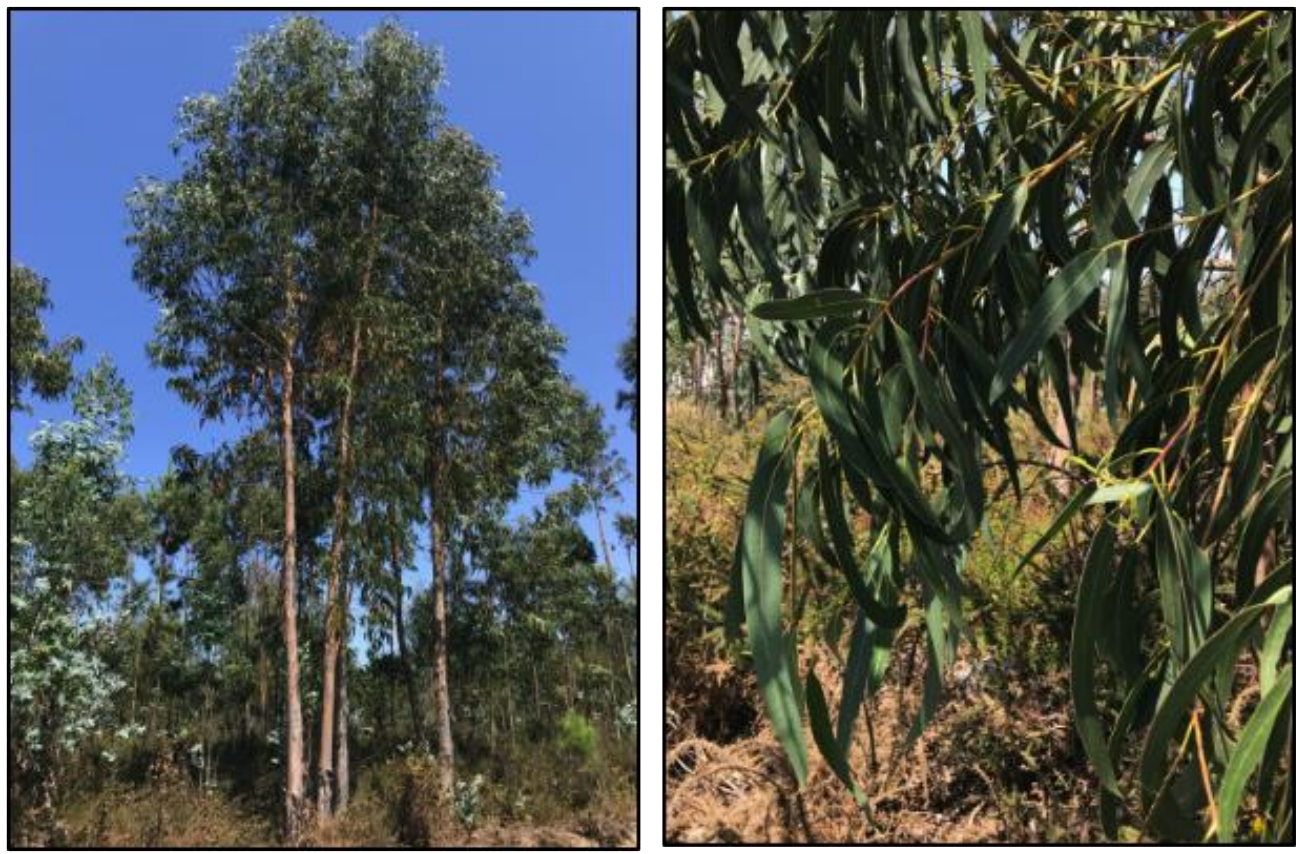

Figure 2. E. globulus plantation in Oliveira de Azeméis (left) and E. globulus leaves (right).

Traditionally, pulp industry only accepts rolls with diameters greater than $10 \mathrm{~cm}$. Thus, all lower diameters are discarded and not recovered. Its use in other supply chains, such as those in the biomass pellets industry, has neglected this source of biomass, since its properties as a fuel are not the best due to a set of disadvantages common to other forms of residual biomass, namely its low density, high moisture content, and the presence of elements such as chlorine, which during the combustion process can cause damage to the metal surfaces of combustion equipment.

\section{Materials and Methods}

\subsection{Materials}

Six different samples of Eucalyptus globulus were collected, with diameters ranging from 2 to $9 \mathrm{~cm}$. The samples were cut, debarked, dried, ground, and analyzed prior to torrefaction as well as after. For the analysis performed before torrefaction process, eucalyptus samples were divided into trunks, barks, and leaves, and weighed separately, which led to knowledge of the percentage that each portion represents in the collected trees. Since the two smaller tree samples were not big enough for all analyses performed, they were mixed for the torrefaction step and subsequent steps. A weighted average was used for the following calculations.

\subsection{Torrefaction Process}

\subsubsection{Sample Selection and Preparation}

As mentioned above, E. globulus was the selected biomass source. Diameters were measured before cutting to ensure that sizes varied within chosen range. Following the selection, the trees were cut, debarked, and prepared for analysis and torrefaction. The samples that were analyzed before the torrefaction process were divided as previously described, and then dried and ground to comply with the standards. The samples that followed for torrefaction, only the trunks, were dried, cut into smaller pieces, ground, and then wrapped in conventional aluminum foil. 
Equipment used for drying and grinding were an ECOCELL forced air oven and a RETSCH (model SM300) blade mill. Before torrefaction, a 10-mm diameter sieve was used to homogenize the samples, while a 2-mm diameter sieve was used for grinding before the analysis. Since Trees 1 and 2 were mixed before the torrefaction process, there were five samples for each torrefaction test.

\subsubsection{Torrefaction Procedure}

For this study, the equipment of choice was a BARRACHA (model K-3) high-temperature furnace, which uses electrical resistances for the generation of heat. This furnace also presents a built-in thermal controller that enables programming four temperature stages with respective residence times. The preparation of the samples was made with the aid of conventional aluminum paper used to wrap the material into a cylindrical shape. Because the aluminum paper has two distinct sides, it should be noted that the opaque part of the sheet must be directed towards the outside so that during the torrefaction process the heat is not reflected.

The definition of optimal temperature stages and a scheme of the programmable stages are presented in Table 1 , where $\mathrm{T}_{1}$ is approximately $100^{\circ} \mathrm{C}$ and $\mathrm{T}_{2}$ is the torrefaction temperature.

Table 1. Scheme of the furnace's programmable stages according to the temperature and residence time.

\begin{tabular}{cccc}
\hline Stages & Torrefaction Steps & Temperature $\left({ }^{\circ} \mathrm{C}\right)$ & Residence Time (min) \\
\hline 1 & Initial heating/pre-drying & $\mathrm{T}_{\text {room }}-\mathrm{T}_{1}$ & $\mathrm{t}_{1}$ \\
2 & Post-drying and intermediate heating & $\mathrm{T}_{1}-\mathrm{T}_{2}$ & $\mathrm{t}_{2}$ \\
3 & Torrefaction & $\mathrm{T}_{2}$ & $\mathrm{t}_{3}$ \\
4 & Solids cooling & $\mathrm{T}_{2}-50{ }^{\circ} \mathrm{C}$ & $\mathrm{t}_{4}$ \\
\hline
\end{tabular}

\subsubsection{Torrefaction Parameters}

As mentioned above, torrefaction process was repeated several times with a variation in two parameters. Different temperatures and residence times were chosen, and each torrefied product was analyzed to ensure that the best combination of the two would lead to the desired result. When compared to the previously specified steps, it is important to highlight that Steps 1 and 2 were combined and that temperatures of the stages did not follow the definitions mentioned by Bergman [63]. Temperatures were chosen based on the torrefaction temperature range, as defined by Nunes (2020) [70], while the residence times were selected based on the study by Ribeiro et al. [74]. Table 2 presents the parameters used in each one of the tests performed along with their identification.

Table 2. Chosen torrefaction parameters.

\begin{tabular}{cccc}
\hline Torrefaction & $\mathbf{t}_{\mathbf{R}}(\mathbf{m i n})$ & $\mathbf{T}_{\mathbf{1}}\left({ }^{\circ} \mathbf{C}\right)$ & $\mathbf{T}_{\mathbf{2}}\left({ }^{\circ} \mathbf{C}\right)$ \\
\hline Tor 1 & 60 & & \\
Tor 2 & 90 & 150 & 240 \\
Tor 3 & 120 & & \\
\hline Tor 4 & 60 & & \\
Tor 5 & 90 & 175 & 280 \\
Tor 6 & 120 & & \\
Tor 7 & 60 & & 320 \\
Tor 8 & 90 & 200 & \\
Tor 9 & 120 & & \\
\hline
\end{tabular}

\subsection{Laboratorial Characterization of the Samples}

\subsubsection{Initial Moisture Content}

As soon as the samples were cut, a small piece of each portion (trunk, bark, and leaves) was used to determine the initial moisture content of each tree. The pieces were weighed, put in a container, 
and placed in a forced-air oven. Every $3 \mathrm{~h}$, each piece was weighed until all moisture had evaporated. Lastly, Equation (1) was applied to obtain the initial moisture content $\left(\mathrm{M}_{1}\right)$ :

$$
\mathrm{M}_{1}(\%)=\left(\frac{\mathrm{w}_{\text {initial }}-\mathrm{w}_{\text {final }}}{\mathrm{w}_{\text {initial }}}\right) \times 100
$$

where $\mathrm{w}_{\text {initial }}$ is the initial mass and $\mathrm{w}_{\text {final }}$ is the final mass, and was only analyzed before torrefaction.

\subsubsection{Chlorine Content}

Chlorine is usually present in biomass in low concentrations [84,85]. However, during combustion, hydrochloric acid is formed, which can lead to corrosion in the furnace [86-88]. Therefore, it is crucial to determine the torrefaction temperature that will eliminate that component. Chloride titration was the method chosen to determine the chlorine content, and the equipment used was a TITROLINE 7000 titrator from SI Analytics. For this procedure, sample preparation involves previous digestion of the sample, performed in a SINEO MDS-6G microwave, since titration requires a liquid sample. Chlorine content determination is achieved by potentiometric titration. This method consists of measuring the potential difference while the titrant, in this case, $\mathrm{AgNO}_{3}$, is added. Equation (2) presents the redox reaction that occurs:

$$
\mathrm{Cl}^{-} \text {(aq.) }+\mathrm{AgNO}_{3} \text { (aq.) } \rightarrow \mathrm{AgCl}\left(\text { s) }+\mathrm{NO}_{3}^{-} \text {(aq.) },\right.
$$

As the next step, software creates a spreadsheet with the potential difference and titrant volume variation over time. The first derivative can then be calculated through Equation (3) and the equivalence point can be determined as the volume corresponding to the maximum of the first derivative:

$$
\mathrm{f}^{\prime}(\mathrm{x})=\frac{\Delta \mathrm{U}}{\Delta \mathrm{V}}=\frac{\mathrm{U}_{\mathrm{i}}-\mathrm{U}_{\mathrm{i}-1}}{\mathrm{~V}_{\mathrm{i}}-\mathrm{V}_{\mathrm{i}-1}}
$$

where $\Delta \mathrm{U}$ is the potential difference variation $(\mathrm{mV})$ and $\Delta \mathrm{V}$ is the volume variation $(\mathrm{mL})$.

Chlorine content on a dry basis $\left(\mathrm{w}_{\mathrm{Cl}, \mathrm{db}}\right)$ is then determined by Equation (4), in compliance with the European standard EN15289:

$$
\mathrm{w}_{\mathrm{Cl}, \mathrm{db}}(\%)=\frac{\left(\mathrm{C}-\mathrm{C}_{0}\right) \times \mathrm{V}}{\mathrm{m}} \times 100 \times \frac{100}{100-\mathrm{M}_{\mathrm{ad}}},
$$

where $\mathrm{C}$ is the concentration of chloride in the solution $(\mathrm{mg} / \mathrm{L}), \mathrm{C}_{0}$ is the concentration of chloride in the blank solution $(\mathrm{mg} / \mathrm{L}), \mathrm{V}$ is the volume of the solution $(\mathrm{L}), \mathrm{m}$ is the mass of the test portion used in the digestion ( $\mathrm{mg}$ ), and $\mathrm{M}_{\mathrm{ad}}$ is the moisture content in the analysis test sample (\%).

\subsubsection{Major and Minor Elements Analysis}

Inductively coupled plasma atomic emission spectroscopy (ICP-AES), also known as inductively coupled plasma optical emission spectrometry (ICP-OES), is an analytical technique which produces excited atoms and ions that emit electromagnetic radiation at different wavelengths and is used for the determination of trace elements. The main advantages are its multi-element capability, broad dynamic range, and effective background correction [89]. For preparation of the samples, microwave digestion was once again necessary to ensure that the capillaries did not get obstructed. The model used for the analysis was a THERMO SCIENTIFIC (iCAP 6000 series). A peristaltic pump delivered the digested samples to an analytical nebulizer and introduced into the plasma flame that breaks down the samples into charged ions, releasing radiation with specific wavelengths. In the end, software generates a 
spreadsheet with the results. Equations (5) and (6) were used to calculate the content of each element in the sample on a dry basis $\left(w_{i, d b}\right)$, in compliance with standards EN15289, EN15290, and EN15297:

$$
\mathrm{w}_{\mathrm{i}, \mathrm{db}}=\left(\frac{\mathrm{mg}}{\mathrm{kg}}\right)=\frac{\left(\mathrm{C}-\mathrm{C}_{\mathrm{i}, 0}\right) \times \mathrm{V}}{\mathrm{m}} \times \frac{100}{100-\mathrm{M}_{\mathrm{ad}}},
$$

where $C_{i}$ is the concentration of the element in the diluted sample digest $(\mathrm{mg} / \mathrm{L}), \mathrm{C}_{\mathrm{i}, 0}$ is the concentration of the element in the solution of the blank experiment $(\mathrm{mg} / \mathrm{L}), \mathrm{V}$ is the volume of the diluted sample digest solution ( $\mathrm{mL}$ ), $\mathrm{m}$ is the mass of the test portion used $(\mathrm{g})$, and $\mathrm{M}_{\mathrm{ad}}$ is the moisture content in the analysis test sample (\%).

$$
\mathrm{w}_{\mathrm{S}, \mathrm{db}}(\%)=\frac{\left(\mathrm{C}-\mathrm{C}_{0}\right) \times \mathrm{V}}{\mathrm{m}} \times 0.3338 \times 100 \times \frac{100}{100-\mathrm{M}_{\mathrm{ad}}},
$$

where $C_{i}$ is the concentration of sulfate in the solution $(\mathrm{mg} / \mathrm{L}), \mathrm{C}_{\mathrm{i}, 0}$ is the concentration of sulfate in the solution of the blank experiment $(\mathrm{mg} / \mathrm{L}), \mathrm{V}$ is the volume of the diluted sample digest solution $(\mathrm{mL}), \mathrm{m}$ is the mass of the test portion used (g), 0.3338 is the stoichiometric ratio of the relative molar masses of sulfur and sulfate, and $\mathrm{M}_{\mathrm{ad}}$ is the moisture content in the analysis test sample (\%).

\subsubsection{Elemental Analysis}

Elemental analysis was performed in a LECO CHN628. The operational principle consists of weighing a sample in a tin foil that is later placed in the autoloader. The sample is then introduced into the primary furnace containing only pure oxygen, which results in fast and complete combustion. Carbon, hydrogen, and nitrogen present in the sample are oxidized to $\mathrm{CO}_{2}, \mathrm{H}_{2} \mathrm{O}$, and $\mathrm{NO}_{\mathrm{x}}$, respectively, and are swept by the oxygen carrier gas through a secondary furnace for further oxidation and particulate removal. Detection of $\mathrm{H}_{2} \mathrm{O}$ and $\mathrm{CO}_{2}$ occurs through separate, optimized, non-dispersive infrared cells, while the $\mathrm{NO}_{\mathrm{x}}$ gases are reduced to $\mathrm{N}$. Lastly, $\mathrm{N}_{2}$ is detected when the gas passes through a thermal conductivity cell. After the analysis is complete, moisture content obtained through thermogravimetric analysis is introduced into the software and the CHN contents are automatically calculated. Following that, it is possible to estimate the oxygen content on a dry basis $\left(\mathrm{w}_{\mathrm{O}, \mathrm{db}}\right)$ from Equation (7):

$$
\mathrm{w}_{\mathrm{O}, \mathrm{db}}(\%)=100-\mathrm{w}_{\mathrm{C}, \mathrm{db}}-\mathrm{w}_{\mathrm{H}, \mathrm{db}}-\mathrm{w}_{\mathrm{N}, \mathrm{db}}-\mathrm{w}_{\mathrm{S} . \mathrm{db}}-\mathrm{w}_{\mathrm{Cl}, \mathrm{db}},
$$

where $\mathrm{w}_{\mathrm{C}, \mathrm{db}}$ is the carbon content on a dry basis $(\%), \mathrm{w}_{\mathrm{H}, \mathrm{db}}$ is the hydrogen content on a dry basis (\%), $\mathrm{w}_{\mathrm{N}, \mathrm{db}}$ is the nitrogen content on a dry basis $(\%), \mathrm{w}_{\mathrm{S}, \mathrm{db}}$ is the sulfur content on a dry basis (\%), and $\mathrm{w}_{\mathrm{Cl}, \mathrm{db}}$ is the chlorine content on a dry basis $(\%)$.

\subsubsection{Proximate Analysis}

The proximate analysis consists in the determination of ash, moisture, fixed carbon, and volatile matter content, which makes it crucial for the thermal conversion of biomass [90]. These values can affect not only the combustion behavior, but also plant design since high moisture content decreases heating value, and the presence of ash influences corrosion and slag formation [91]. Proximate analysis by thermogravimetry enables study of mass loss of the sample in a controlled environment as a function of the temperature [92].

The thermogravimetric analyzer used was an ELTRA THERMOSTEP model. One gram of each sample was introduced into crucibles and placed inside an oven, along with an empty reference crucible. As temperature increased, crucibles were weighed on a precision scale. Moisture, volatiles, and fixed carbon content were determined in this order throughout the heating process. Lastly, the final residue represents the ash content. 


\subsubsection{Heating Value}

Heating value, also known as the calorific value, defines the energy content of biomass fuel [93]. This parameter can be described in two ways: higher heating value (HHV) or gross calorific value refers to the heat released from fuel combustion along with the vaporization energy from water, while lower heating value (LHV) or net calorific value is based on steam as the product, which means its vaporization energy is not considered heat [35].

The heating value of biomass, both higher and lower, can be determined experimentally by employing an adiabatic bomb calorimeter. The model used in this project was the 6400 Automatic Isoperibol Calorimeter by PARR INSTRUMENT. After each procedure, the equipment provides the corrected temperature increase that is later used for the determination of the heating value. Due to the nitrogen- and oxygen-rich atmosphere inside the calorimeter, nitric acid and sulfuric acid are formed, respectively, and the heat of formation of both acids must be disregarded. For $\mathrm{HNO}_{3}$, the wash water for the pump was titrated with $\mathrm{NaOH}(0.1 \mathrm{M})$ and Equation (8) was applied, while for $\mathrm{H}_{2} \mathrm{SO}_{4}$, knowing the sulfur content, Equation (9) can be applied:

$$
\mathrm{Q}_{\mathrm{N}, \mathrm{S}}=1.43 \times \mathrm{V}_{\mathrm{NaOH}},
$$

where $\mathrm{Q}_{\mathrm{N}, \mathrm{S}}$ is the heat contribution relative to nitric acid formation (cal) and $\mathrm{V}_{\mathrm{NaOH}}$ is the volume of $\mathrm{NaOH}$ used in the titration of the wash water of the pump $(\mathrm{mL})$.

$$
\mathrm{Q}_{\mathrm{S}, \mathrm{add}}=13.61 \times \mathrm{w}_{\mathrm{S}, \mathrm{db}},
$$

where $\mathrm{Q}_{\mathrm{S} \text {,add }}$ is the additional contribution relative to sulfur dioxide formation and $\mathrm{w}_{\mathrm{S}, \mathrm{db}}$ is the sulfur content on a dry basis (\%).

With this information, Equation (10) can be applied to obtain the gross calorific value, or high heating value, at a constant volume, $\mathrm{q}_{\mathrm{V}, \mathrm{gr}}(\mathrm{J} / \mathrm{g})$ :

$$
\mathrm{q}_{\mathrm{V}, \mathrm{gr}}=\left(\frac{\varepsilon \times \theta-\mathrm{Q}_{\text {thread }}-\mathrm{Q}_{\mathrm{N}, \mathrm{S}}}{\mathrm{m}}-\mathrm{Q}_{\mathrm{S}, \text { add }}\right) \times 4.1868,
$$

where $\varepsilon$ is the calorific capacity of the calorimeter (previously determined) $\left(\mathrm{cal} /{ }^{\circ} \mathrm{C}\right), \theta$ is the corrected temperature increase $\left({ }^{\circ} \mathrm{C}\right), \mathrm{Q}_{\text {thread }}$ is the heat contribution relative to the thread combustion $(\mathrm{cal}), \mathrm{Q}_{\mathrm{N}, \mathrm{S}}$ is the heat contribution relative to nitric acid formation (cal), $\mathrm{Q}_{\mathrm{s} \text {,add }}$ is the additional contribution relative to sulfur dioxide formation (cal), and $\mathrm{m}$ is the mass of the sample (g).

Equation (11) was used to calculate the gross calorific value at constant volume on a dry basis, $\mathrm{q}_{\mathrm{v}, \mathrm{gr}, \mathrm{db}}(\mathrm{J} / \mathrm{g})$ :

$$
\mathrm{q}_{\mathrm{V}, \mathrm{gr}, \mathrm{db}}=\mathrm{q}_{\mathrm{V}, \mathrm{gr}} \times \frac{100}{100-\mathrm{M}_{\mathrm{ad}}},
$$

where $\mathrm{q}_{\mathrm{V}, \mathrm{gr}, \mathrm{db}}$ is the gross calorific value at constant volume $(\mathrm{J} / \mathrm{g})$ and $\mathrm{M}_{\mathrm{ad}}$ is the moisture content in the analysis test sample (\%). Lastly, the net calorific value at constant pressure on a dry basis, $\mathrm{q}_{\mathrm{p}, \mathrm{net}, \mathrm{db}}$ $(\mathrm{J} / \mathrm{g})$, can be calculated through Equation (12):

$$
\mathrm{q}_{\mathrm{p}, \text { net,db }}=\mathrm{q}_{\mathrm{V}, \mathrm{gr}, \mathrm{db}}-212.2 \times \mathrm{w}_{\mathrm{H}, \mathrm{db}}-0.8 \times\left(\mathrm{w}_{\mathrm{O}, \mathrm{db}}+\mathrm{w}_{\mathrm{N}, \mathrm{db}}\right),
$$

where $\mathrm{q}_{\mathrm{V}, \mathrm{gr}, \mathrm{db}}$ is the gross calorific value at constant volume on a dry basis $(\mathrm{J} / \mathrm{g}), \mathrm{w}_{\mathrm{H}, \mathrm{db}}$ is the hydrogen content on a dry basis (\%), $\mathrm{w}_{\mathrm{O}, \mathrm{db}}$ is the oxygen content on a dry basis $(\%)$, and $\mathrm{w}_{\mathrm{N}, \mathrm{db}}$ is the nitrogen content on a dry basis (\%). It should be noted that the oxygen content used in Equation (12) is not the same as that calculated in Equation (13). According to the European standard EN14918, $\left(\mathrm{w}_{\mathrm{O}, \mathrm{db}}+\right.$ $\mathrm{w}_{\mathrm{N}, \mathrm{db}}$ ) is obtained from Equation (13):

$$
\left(w_{O, d b}+W_{N, d b}\right)=100-w_{A, d b}-w_{C, d b}-w_{H, d b}-w_{S, d b},
$$


where $\mathrm{w}_{\mathrm{A}, \mathrm{db}}$ is the ash content on a dry basis $(\%), \mathrm{w}_{\mathrm{C}, \mathrm{db}}$ is the carbon content on a dry basis $(\%), \mathrm{w}_{\mathrm{H}, \mathrm{db}}$ is the hydrogen content on a dry basis (\%), and $\mathrm{w}_{\mathrm{S}, \mathrm{db}}$ is the sulfur content on a dry basis (\%).

\subsubsection{Energy Density and Mass and Energy Yield}

Lastly, parameters such as the energy densification ratio (EDR), mass yield ratio (MYR), and energy yield (EY) were analyzed. The calculations were made using Equations (11)-(13), according to Grigiante and Antolini (2014) [94]:

$$
\mathrm{EDR}=\frac{\mathrm{HHV}_{\text {dried torrefied biomass }}}{\mathrm{HHV}_{\text {dried raw biomass }}},
$$

where $\mathrm{HHV}_{\text {dried torrefied biomass }}$ is the high heating value of the dried torrefied biomass and $\mathrm{HHV}_{\text {dried raw biomass }}$ is the high heating value of the dried raw biomass.

$$
\operatorname{MYR}(\%)=\frac{\mathrm{w}_{\text {dried torrefied biomass }}}{\mathrm{w}_{\text {dried raw biomass }}} \times 100,
$$

where $\mathrm{w}_{\text {dried }}$ torrefied biomass is the mass of the dried torrefied biomass and $\mathrm{w}_{\text {dried raw biomass }}$ is the mass of the dried raw biomass.

$$
\mathrm{EY}(\%)=\mathrm{MYR} \times \mathrm{EDR},
$$

where MYR is the mass yield ratio (\%) and EDR is the energy densification ratio.

\section{Results and Discussion}

\subsection{Mass Distribution and Initial Moisture Content}

As mentioned above, the first task was to divide trees into trunks, bark, and leaves. All samples were weighed as soon as they were separated, and a portion of each sample followed to the forced air oven for initial moisture content determination. An example of the material before and after the procedure is presented in Figure 3.
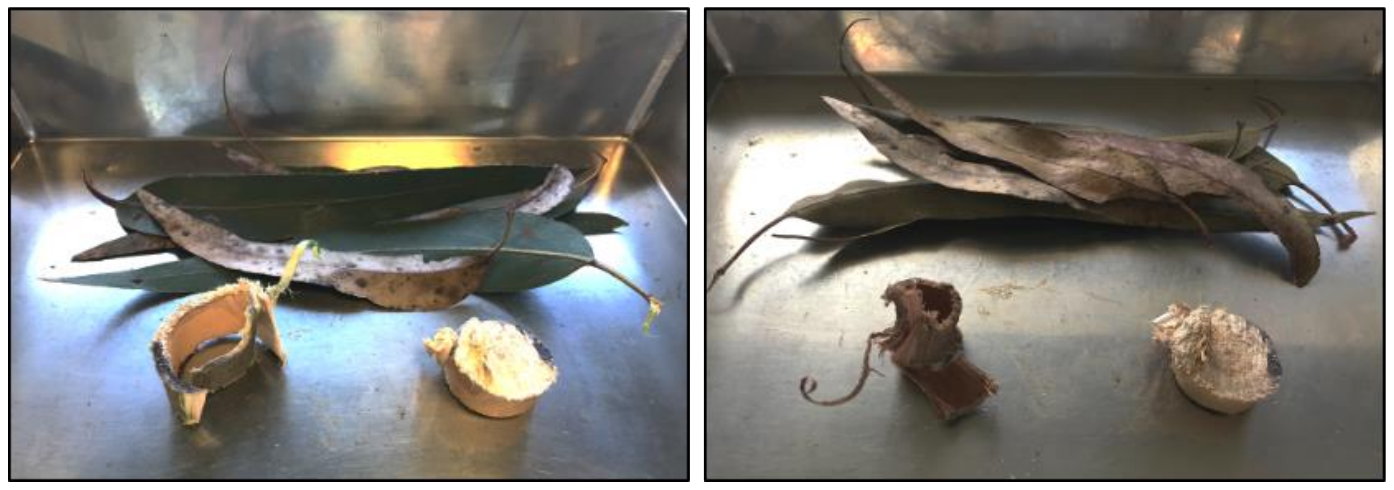

Figure 3. Example of the pieces before (left) and after (right) moisture evaporation.

The contribution of each section to the total mass of the tree can be seen in Figure 4. It is possible to observe that Trees 5 and 6 have a more significant contribution from the trunks, which is expected since it is denser. From that, it can be concluded that the older is the tree, the higher is the trunk contribution. All this information is vital since the focus of the pulp and paper industry are the trunks; the bark and leaves are important biomass components that should be used for other applications, such as to produce thermal or electric energy. 


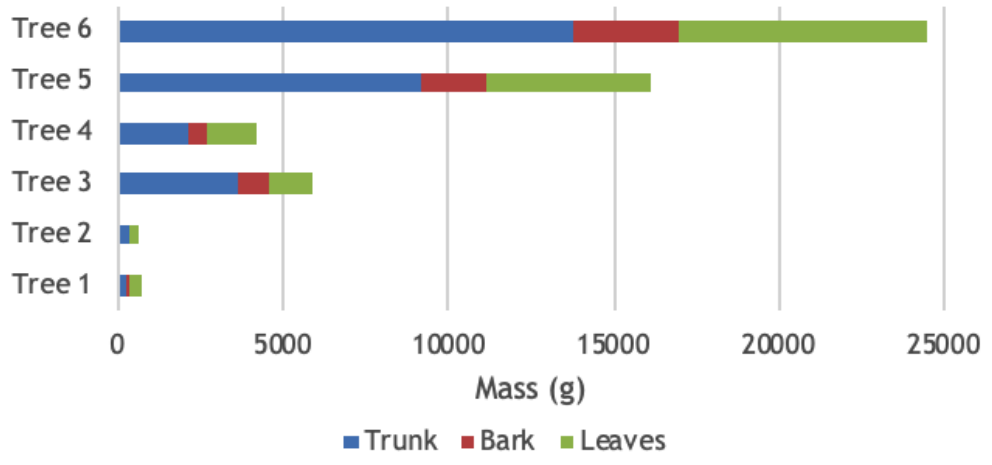

Figure 4. Mass distribution of non-dried biomass.

Initial moisture content is another essential factor, especially for energy purposes. Table 3 presents obtained results. Torrefaction process can be implemented as a pretreatment to improve this property for subsequent conversion processes.

Table 3. Initial moisture content by section.

\begin{tabular}{cccc}
\hline Tree & Trunk (\%) & Bark (\%) & Leaves (\%) \\
\hline 1 & 54.71 & 63.75 & 47.30 \\
2 & 54.71 & 63.75 & 47.30 \\
3 & 41.74 & 55.27 & 41.10 \\
4 & 45.51 & 52.01 & 40.88 \\
5 & 50.08 & 63.23 & 49.63 \\
6 & 53.32 & 62.50 & 51.52 \\
\hline
\end{tabular}

\subsection{Chlorine Content}

Determination of the temperature at which chlorine disappears is the main focus of this project and this the first study conducted on this subject. The original chlorine content for E. globulus was approximately $0.04 \%$, depending on its location, which agrees with the values obtained in previous studies $[95,96]$. As mentioned above, torrefaction processes were performed in nine different conditions for subsequent analysis. Table 2 presents the temperature stages for tests Tor 1 to Tor 9 , and the chlorine content variation for the process is presented in Tables 4-13.

Table 4. Elemental analysis results, as well as sulfur and chlorine content results.

\begin{tabular}{|c|c|c|c|c|c|c|c|}
\hline \multirow{2}{*}{ Test } & \multirow{2}{*}{ Sample } & \multicolumn{3}{|c|}{ CHN (\%) } & \multirow{2}{*}{ S (\%) } & \multirow{2}{*}{$\mathrm{Cl}(\%)$} & \multirow{2}{*}{$\mathrm{O}(\%)$} \\
\hline & & C & $\mathbf{H}$ & $\mathbf{N}$ & & & \\
\hline \multirow{5}{*}{$\begin{array}{c}\text { Raw } \\
\text { biomass }\end{array}$} & 1 & 56.93 & 5.76 & 0.39 & 0.01 & 0.05 & 36.86 \\
\hline & 2 & 57.87 & 5.88 & 0.23 & 0.00 & 0.03 & 35.99 \\
\hline & 3 & 57.75 & 5.85 & 0.19 & 0.01 & 0.04 & 36.17 \\
\hline & 4 & 58.03 & 5.88 & 0.15 & 0.00 & 0.03 & 35.91 \\
\hline & 5 & 56.62 & 5.78 & 0.22 & 0.00 & 0.03 & 37.35 \\
\hline
\end{tabular}

Table 5. Elemental analysis results, as well as sulfur and chlorine content results.

\begin{tabular}{cccccccc}
\hline \multirow{2}{*}{ Test } & \multirow{2}{*}{ Sample } & \multicolumn{3}{c}{ CHN (\%) } & \multirow{2}{*}{ S (\%) } & \multirow{2}{*}{ Cl (\%) } & \multirow{2}{*}{ O (\%) } \\
\cline { 3 - 5 } & & $\mathbf{C}$ & $\mathbf{H}$ & $\mathbf{N}$ & & & \\
\hline \multirow{3}{*}{ Torr 1 } & 1 & 65.08 & 5.18 & 0.26 & 0.00 & 0.00 & 29.48 \\
& 2 & 62.49 & 5.23 & 0.16 & 0.00 & 0.00 & 32.12 \\
& 3 & 64.04 & 5.25 & 0.19 & 0.00 & 0.00 & 30.52 \\
& 4 & 62.73 & 5.28 & 0.15 & 0.00 & 0.00 & 31.84 \\
& 5 & 65.02 & 5.14 & 0.16 & 0.00 & 0.00 & 29.68 \\
\hline
\end{tabular}


Table 6. Elemental analysis results, as well as sulfur and chlorine content results.

\begin{tabular}{cccccccc}
\hline \multirow{2}{*}{ Test } & \multirow{2}{*}{ Sample } & \multicolumn{3}{c}{ CHN (\%) } & \multirow{2}{*}{ S (\%) } & \multirow{2}{*}{ Cl (\%) } & O (\%) \\
\cline { 2 - 5 } & & $\mathbf{C}$ & $\mathbf{H}$ & $\mathbf{N}$ & & & \\
\hline \multirow{3}{*}{ Torr 2 } & 72.27 & 4.95 & 0.28 & 0.00 & 0.00 & 22.50 \\
& 2 & 67.59 & 5.12 & 0.19 & 0.00 & 0.00 & 27.10 \\
& 3 & 69.56 & 5.06 & 0.20 & 0.00 & 0.00 & 25.18 \\
& 4 & 67.48 & 5.19 & 0.19 & 0.00 & 0.00 & 27.14 \\
& 5 & 68.92 & 5.03 & 0.20 & 0.00 & 0.00 & 25.85 \\
\hline
\end{tabular}

Table 7. Elemental analysis results, as well as sulfur and chlorine content results.

\begin{tabular}{cccccccc}
\hline \multirow{2}{*}{ Test } & \multirow{2}{*}{ Sample } & \multicolumn{3}{c}{ CHN (\%) } & \multirow{2}{*}{ S (\%) } & \multirow{2}{*}{ Cl (\%) } & O (\%) \\
\cline { 2 - 5 } & & $\mathbf{C}$ & $\mathbf{H}$ & $\mathbf{N}$ & & & \\
\hline \multirow{3}{*}{ Torr 3 } & 72.30 & 5.02 & 0.34 & 0.00 & 0.00 & 22.34 \\
& 2 & 68.31 & 5.32 & 0.20 & 0.00 & 0.00 & 26.17 \\
& 3 & 72.37 & 5.05 & 0.19 & 0.00 & 0.00 & 22.39 \\
& 4 & 69.35 & 5.25 & 0.16 & 0.00 & 0.00 & 25.24 \\
& 5 & 74.25 & 4.84 & 0.21 & 0.00 & 0.00 & 20.70 \\
\hline
\end{tabular}

Table 8. Elemental analysis results, as well as sulfur and chlorine content results.

\begin{tabular}{cccccccc}
\hline \multirow{2}{*}{ Test } & Sample & \multicolumn{3}{c}{ CHN (\%) } & \multirow{2}{*}{ S (\%) } & \multirow{2}{*}{ Cl (\%) } & O (\%) \\
\cline { 2 - 5 } & & $\mathbf{C}$ & $\mathbf{H}$ & $\mathbf{N}$ & & & \\
\hline \multirow{3}{*}{ Torr 4} & 1 & 64.48 & 5.20 & 0.26 & 0.00 & 0.00 & 30.06 \\
& 2 & 62.10 & 5.30 & 0.16 & 0.00 & 0.00 & 32.44 \\
& 3 & 64.41 & 5.16 & 0.17 & 0.00 & 0.00 & 30.26 \\
& 4 & 63.20 & 5.29 & 0.13 & 0.00 & 0.00 & 31.38 \\
& 5 & 64.18 & 5.22 & 0.15 & 0.00 & 0.00 & 30.45 \\
\hline
\end{tabular}

Table 9. Elemental analysis results, as well as sulfur and chlorine content results.

\begin{tabular}{cccccccc}
\hline \multirow{2}{*}{ Test } & \multirow{2}{*}{ Sample } & \multicolumn{3}{c}{ CHN (\%) } & \multirow{2}{*}{ S (\%) } & Cl (\%) & \multirow{2}{*}{ O (\%) } \\
\cline { 3 - 5 } & & $\mathbf{C}$ & $\mathbf{H}$ & $\mathbf{N}$ & & & \\
\hline \multirow{3}{*}{ Torr 5 } & 72.97 & 4.99 & 0.30 & 0.00 & 0.00 & 21.74 \\
& 2 & 64.06 & 5.48 & 0.14 & 0.00 & 0.00 & 30.32 \\
& 3 & 66.93 & 5.29 & 0.18 & 0.00 & 0.00 & 27.60 \\
& 4 & 66.12 & 5.43 & 0.16 & 0.00 & 0.00 & 28.29 \\
& 5 & 66.87 & 5.29 & 0.18 & 0.00 & 0.00 & 27.66 \\
\hline
\end{tabular}

Table 10. Elemental analysis results, as well as sulfur and chlorine content results.

\begin{tabular}{cccccccc}
\hline \multirow{2}{*}{ Test } & \multirow{2}{*}{ Sample } & \multicolumn{3}{c}{ CHN (\%) } & \multirow{2}{*}{ S (\%) } & Cl (\%) & O (\%) \\
\cline { 2 - 5 } & & $\mathbf{C}$ & $\mathbf{H}$ & $\mathbf{N}$ & & & \\
\hline \multirow{4}{*}{ Torr 6 } & 7 & 78.42 & 4.22 & 0.35 & 0.00 & 0.00 & 17.01 \\
& 2 & 68.64 & 5.05 & 0.19 & 0.00 & 0.00 & 26.12 \\
& 3 & 72.04 & 4.95 & 0.19 & 0.00 & 0.00 & 22.82 \\
& 4 & 70.25 & 4.95 & 0.16 & 0.00 & 0.00 & 24.64 \\
& 5 & 70.62 & 5.01 & 0.20 & 0.00 & 0.00 & 24.17 \\
\hline
\end{tabular}


Table 11. Elemental analysis results, as well as sulfur and chlorine content results.

\begin{tabular}{cccccccc}
\hline \multirow{2}{*}{ Test } & \multirow{2}{*}{ Sample } & \multicolumn{3}{c}{ CHN (\%) } & \multirow{2}{*}{ S (\%) } & \multirow{2}{*}{ Cl (\%) } & O (\%) \\
\cline { 2 - 5 } & & $\mathbf{C}$ & $\mathbf{H}$ & $\mathbf{N}$ & & & \\
\hline \multirow{3}{*}{ Torr 7 } & 1 & 92.76 & 2.72 & 0.39 & 0.00 & 0.00 & 4.13 \\
& 2 & 89.95 & 2.75 & 0.29 & 0.00 & 0.00 & 7.01 \\
& 3 & 89.94 & 2.74 & 0.25 & 0.00 & 0.00 & 7.07 \\
& 4 & 90.19 & 3.00 & 0.24 & 0.00 & 0.00 & 6.57 \\
& 5 & 90.94 & 2.85 & 0.24 & 0.00 & 0.00 & 5.97 \\
\hline
\end{tabular}

Table 12. Elemental analysis results, as well as sulfur and chlorine content results.

\begin{tabular}{cccccccc}
\hline \multirow{2}{*}{ Test } & \multirow{2}{*}{ Sample } & \multicolumn{3}{c}{ CHN (\%) } & \multirow{2}{*}{ S (\%) } & \multirow{2}{*}{ Cl (\%) } & O (\%) \\
\cline { 2 - 5 } & & $\mathbf{C}$ & $\mathbf{H}$ & $\mathbf{N}$ & & & \\
\hline \multirow{4}{*}{ Torr 8} & 1 & 94.31 & 2.70 & 0.47 & 0.00 & 0.00 & 2.52 \\
& 2 & 91.05 & 2.57 & 0.22 & 0.00 & 0.00 & 6.16 \\
& 3 & 93.07 & 2.74 & 0.23 & 0.00 & 0.00 & 3.96 \\
& 4 & 91.44 & 2.34 & 0.16 & 0.00 & 0.00 & 6.06 \\
& 5 & 92.40 & 2.56 & 0.24 & 0.00 & 0.00 & 4.80 \\
\hline
\end{tabular}

Table 13. Elemental analysis results, as well as sulfur and chlorine content results.

\begin{tabular}{cccccccc}
\hline \multirow{2}{*}{ Test } & \multirow{2}{*}{ Sample } & \multicolumn{3}{c}{ CHN (\%) } & \multirow{2}{*}{ S (\%) } & \multirow{2}{*}{ Cl (\%) } & O (\%) \\
\cline { 2 - 5 } & & $\mathbf{C}$ & $\mathbf{H}$ & $\mathbf{N}$ & & & \\
\hline \multirow{3}{*}{ Torr 9 } & 93.61 & 2.85 & 0.39 & 0.00 & 0.00 & 3.15 \\
& 2 & 96.40 & 2.44 & 0.29 & 0.00 & 0.00 & 0.87 \\
& 3 & 92.59 & 2.96 & 0.33 & 0.00 & 0.00 & 4.12 \\
& 4 & 91.04 & 2.75 & 0.24 & 0.00 & 0.00 & 5.97 \\
& 5 & 91.58 & 2.52 & 0.24 & 0.00 & 0.00 & 5.66 \\
\hline
\end{tabular}

From the data, it is noticeable that chlorine content is undetectable for most of the samples. A possible explanation for some residual chlorine is that during the tests, the element remained attached to the aluminum foil that wrapped the samples, which would not happen in an industrial procedure. Once the chlorine content was already zero for the less intense torrefaction, Tor 1, it was not possible to determine the temperature at which chlorine disappears. This observation is of particular importance, as it allows to deduce that it is possible to eliminate chlorine at lower temperatures than those used during torrefaction process. That is, most likely, it will be possible to eliminate chlorine in more intense drying processes, thus avoiding damages caused by chlorine in the torrefaction equipment, such as those reported by Nunes (2020) [70]. However, this aspect must be confirmed by new research, since it is also necessary to determine whether if, in addition to temperature, residence time also has a direct influence on the chlorine elimination process, or if it is capable, as an alternative to the increment in temperature, to contribute to the acceleration of the process. Thus, considering the use of an industrial scale process, after measuring the temperature, it may be sufficient to subject the materials to be treated, to a longer residence time.

\subsection{Elemental Analysis}

Elemental analysis was performed in a $\mathrm{CHN}$ elemental analyzer. However, for calculation of the oxygen content, sulfur and chlorine content were also used, as stated in Equation (7). Prior to torrefaction, sulfur content was obtained through ICP-OES since it was not possible to perform this analysis afterwards and the initial content was already low. A behavior similar to chlorine was assumed for calculation purposes. Chlorine content was obtained through chloride titration both 
before and after torrefaction. Carbon content increased with torrefaction and was intensified with higher temperatures, while hydrogen content displayed the opposite response.

Tables 4-13 present the results obtained for CHN, including the calculated oxygen content. From the results, it was possible to calculate the $\mathrm{H} / \mathrm{C}$ and $\mathrm{O} / \mathrm{C}$ ratios to be used in the van Krevelen diagram, presented in Figure 5.

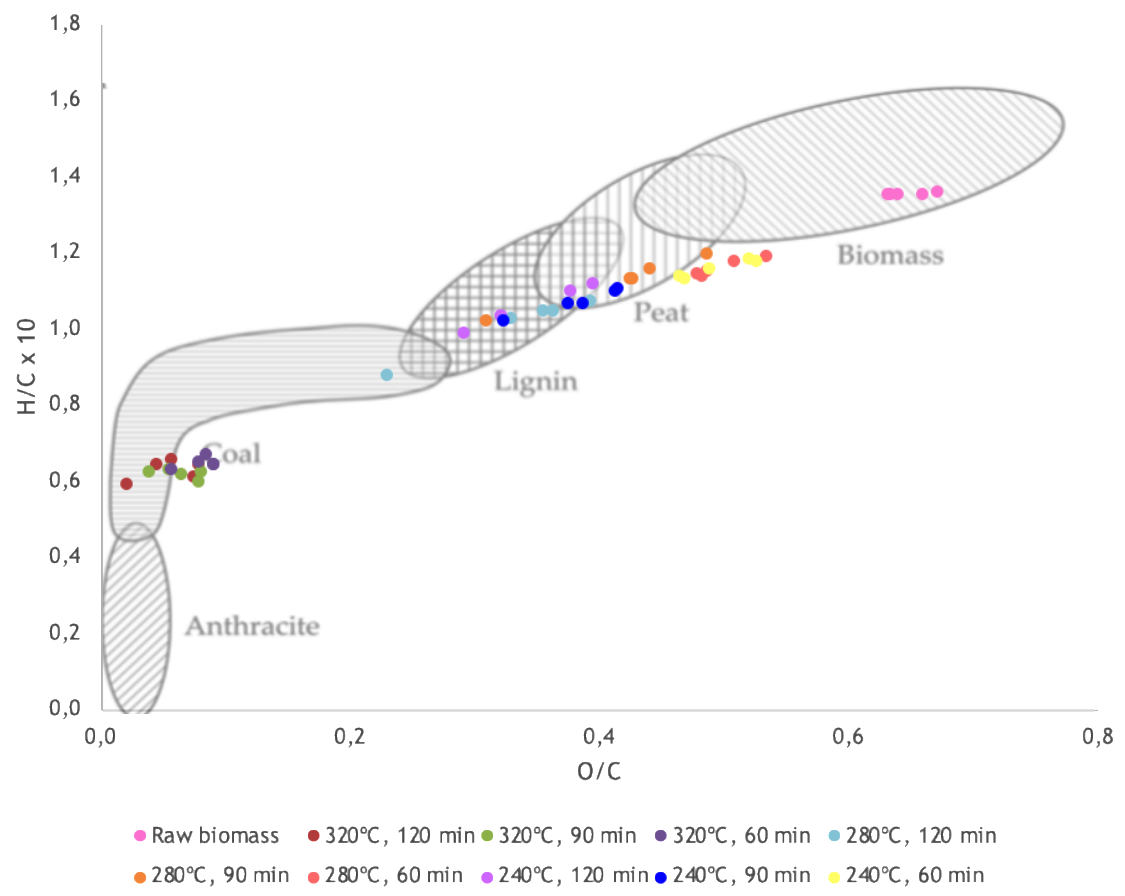

Figure 5. Van Krevelen diagram representation of the raw and torrefied materials comparatively to traditional biomass forms and coal products.

Through the analysis of Figure 5, it is possible to see that samples that were torrefied at $320^{\circ} \mathrm{C}$ are close to the Coal zone of the diagram, as expected. During torrefaction, oxygen and hydrogen are removed from the samples, leading to a solid product with lower O/C and H/C ratios. Samples that went through less intense torrefaction at 280 and $240{ }^{\circ} \mathrm{C}$, showed an improvement when compared to initial raw biomass, even though $\mathrm{H} / \mathrm{C}$ and $\mathrm{O} / \mathrm{C}$ ratios were still high when compared to coal.

\subsection{Proximate Analysis}

As torrefaction severity increases, both fixed carbon and ash content present in biomass also increase. However, volatile content presents an opposite behavior. Ash content has a significant impact on the process, especially in terms of operating costs. Studies have shown that high ash content leads to fouling and slagging phenomena, which can damage the equipment used in the process. From the results presented in Figure 6, it is possible to confirm that ash content increases with torrefaction at higher temperatures, and fixed carbon increases and volatiles decrease with an increment in temperature. Moreover, it is noticeable that the two properties presented opposite behavior. 

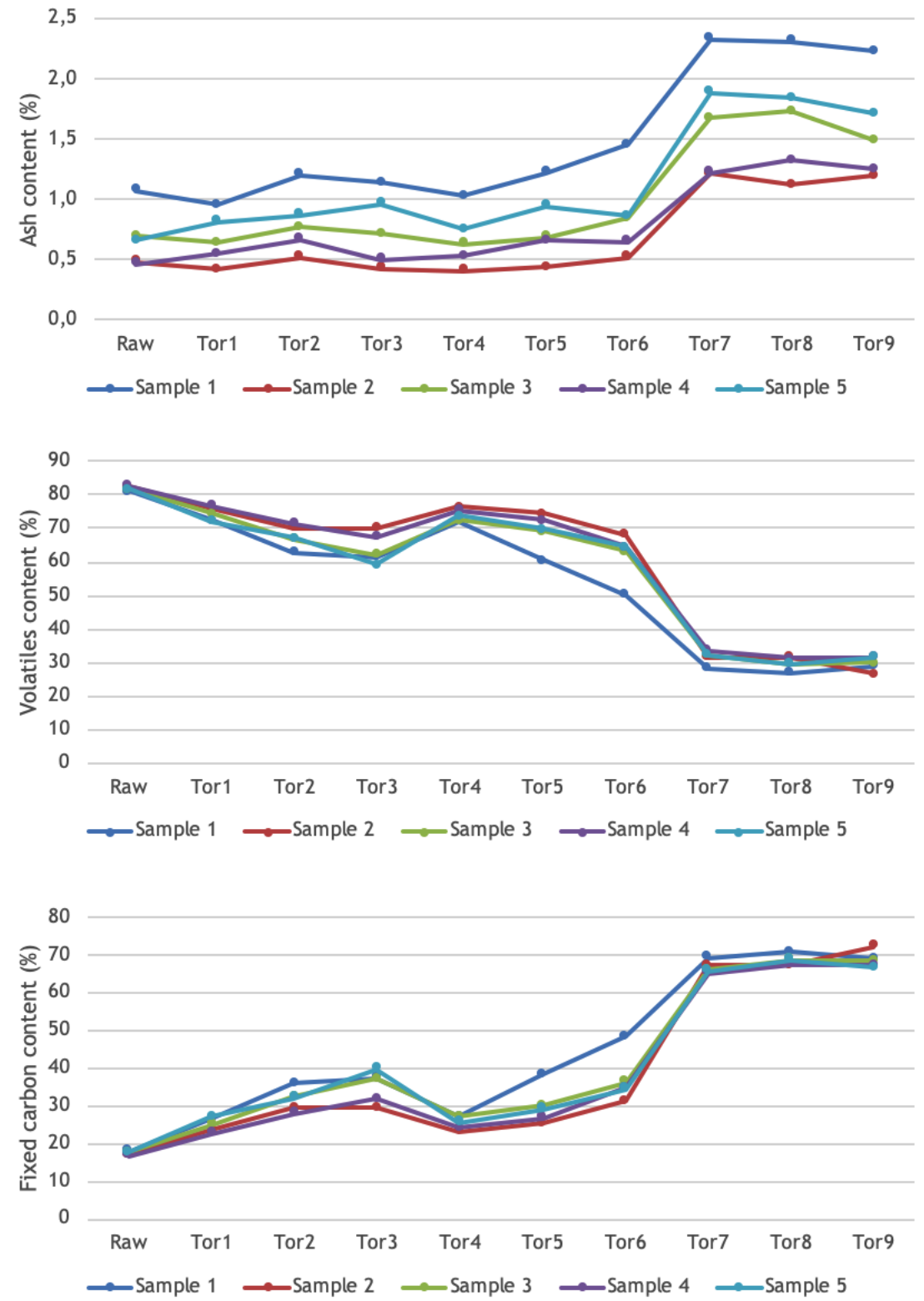

Figure 6. Results for the mass fraction of ash, volatiles, and fixed carbon contents.

\subsection{Heating Value}

Heating value of the samples was obtained through calorimetry. Results are presented in Figure 7. Due to the high values of HHV for the torrefied samples, the calorimeter presented some problems. Although the analysis was performed in triplicate, only the two closest results were used in accordance with the European standard. In Figure 7, it is possible to see that, even though most of the samples presented the expected results, not all of them did. When compared to raw biomass, an increment in HHV of 58\% after torrefaction is in accordance with Chew et al. (2011) [97]. 


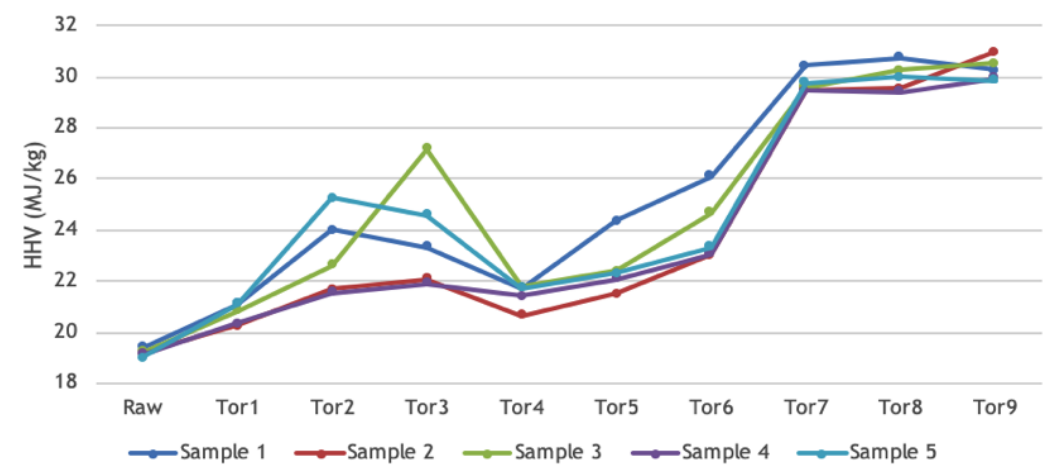

Figure 7. Results for higher heating value (MJ/kg).

\subsection{Energy Density and Mass and Energy Yield}

From the values obtained through calorimetry for the HHV before and after the torrefaction process, it was possible to calculate the energy densification ratio, which is presented graphically in Figure 8 .

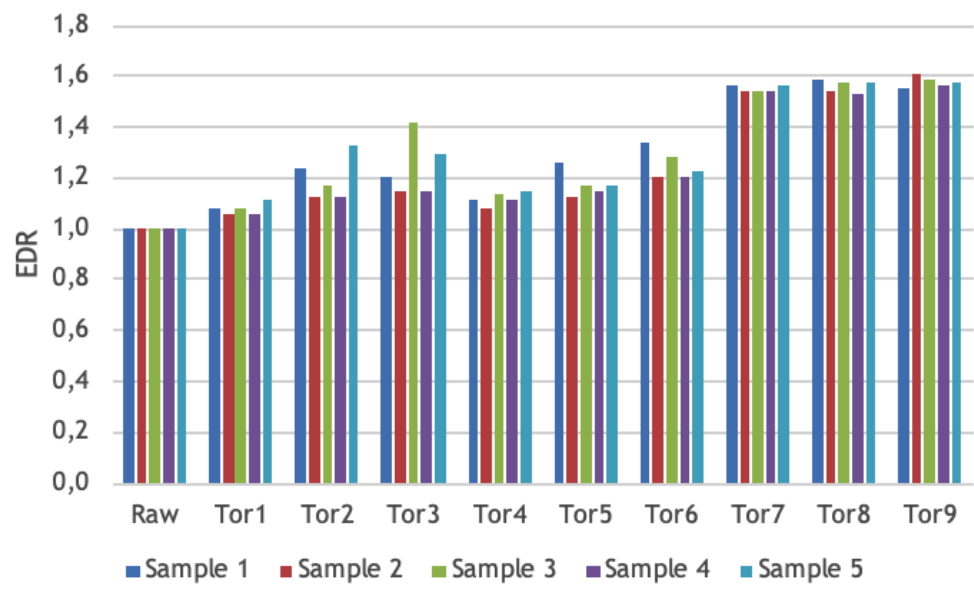

Figure 8. Results for energy densification ratio.

In Equation (14), the energy densification ratio is related to the HHV. Therefore, it is expected that samples with a higher HHV have a higher EDR. The series of torrefaction processes carried out at $320{ }^{\circ} \mathrm{C}$ gave the expected results. However, the series performed at 280 and $240{ }^{\circ} \mathrm{C}$ should be more easily distinguished. All samples were weighed before and after torrefaction. Following Equation (15), it was possible to use these values to calculate the mass yield ratio of each sample, which is presented in Figure 9.

In the figure, it is possible to notice that all samples presented mass loss and that this is more prominent as the intensity of the process increases. The samples that went through Tor 7 displayed mass losses of approximately $25 \%$, which is quite low, considering that the torrefaction temperature was $320^{\circ} \mathrm{C}$, even if the residence time was only $60 \mathrm{~min}$. According to Bergman [63], there is a direct relationship between the mass loss and the increase in energy density. That cannot be said for the samples from Tor 7 but is in accordance with the remaining results presented. Lastly, from Equation (16), the energy yields were calculated for all samples, and they are displayed in Figure 10. 


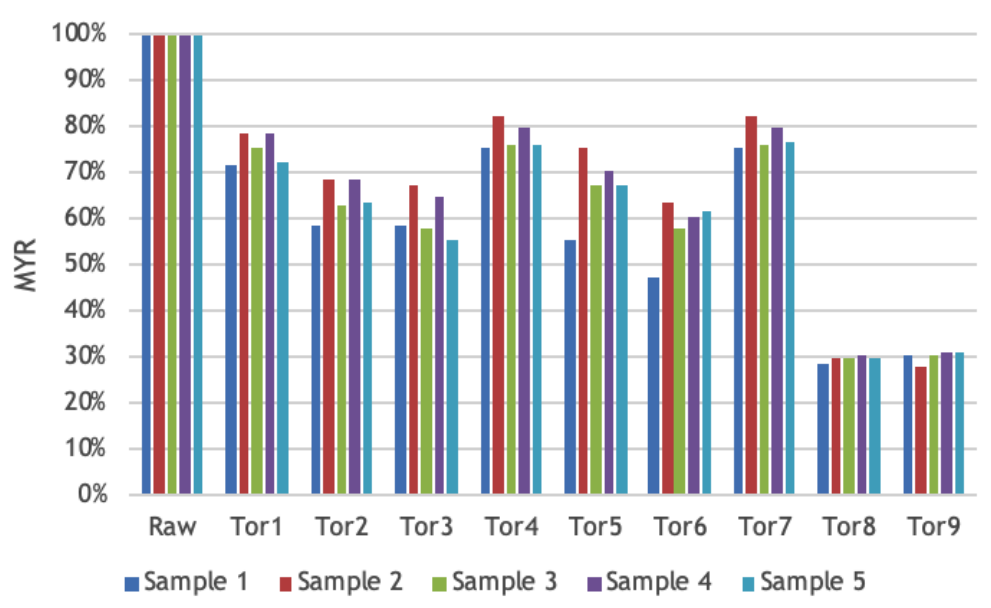

Figure 9. Results for mass yield ratio.

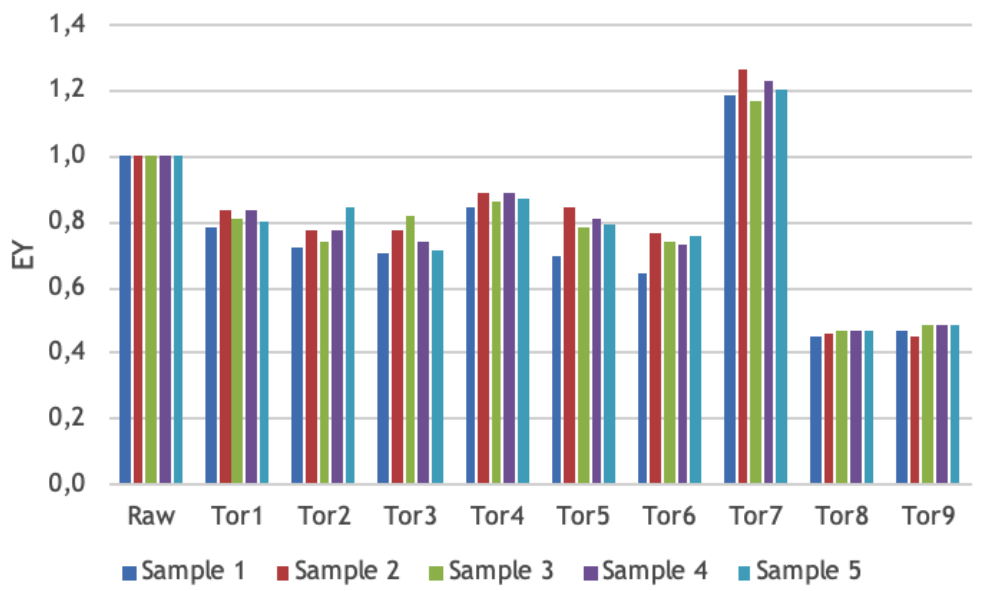

Figure 10. Results for energy yield.

It was expected that, as torrefaction severity increased, energy yield would decrease. This can be explained by the fact that, even though there is an increase in the energy density, the mass loss caused by torrefaction renders samples less energy efficient. Once more, results from Tor 7 disagree with the expectations and display higher values to those from the raw biomass. It should be noted that, since the equipment used for these tests was a ceramic muffle, it was not possible to guarantee that temperature was uniform in the entire furnace since it depends on the performance of each resistance. Therefore, variations in the torrefaction degree could explain some unexpected results.

\section{Conclusions}

The search for alternative energy sources that can minimize environmental impacts of fossil fuels has been a concern for some time. Due to its versatility and high availability, biomass has great potential for the energy sector, mainly because it can be converted into different forms of energy, and thus can be used as an alternative to fossil fuels. Furthermore, unlike what happens with other renewable sources, biomass does not have the problem of intermittent supply, as with wind or sun, thus it can be used as a backup and reserve source. In Portugal, the ever-growing Eucalyptus globulus forest is mainly used by the pulp and paper industry; however. this research studied the incorporation of eucalyptus biomass with diameters of less than $10 \mathrm{~cm}$ in the biomass energy recovery supply chain.

Summarizing, six samples of eucalyptus trees were selected and characterized before the torrefaction process for later comparison. Torrefaction was carried out nine times for three temperatures and three residence times, and, following torrefaction, a new series of analyses took place. As the research demonstrated, moisture content decreased and the HHV increased when higher torrefaction 
temperatures were used, in accordance with the reviewed literature. Carbon content is another important parameter that, according to the results obtained, followed the expected behavior, increasing with higher torrefaction temperatures.

This study successfully determined that at $240{ }^{\circ} \mathrm{C}$ the chlorine content of eucalyptus trees in the selected range was already nonexistent. This new knowledge can contribute to the reduction of operating costs due to the possibility of performing torrefaction at lower temperatures without further concerns related with equipment damaging caused by corrosion.

Since this was the first study conducted on this subject, the selected parameters and the chlorine quantification technique can be improved in future research. Focus on lower temperature ranges, between 220 and $240{ }^{\circ} \mathrm{C}$, or even lower and out of the usually assumed torrefaction temperature range, 220-320 ${ }^{\circ} \mathrm{C}$, with narrower intervals, and the use of quantification methods, such as gas chromatography (GC) or X-ray fluorescence (XRF), may help to determine the exact temperature at which the chlorine is eliminated, and how the process occurs. However, due to the results obtained, which can be considered preliminary, the use of thermal methods to improve the combustibility conditions of residual biomass can be considered as very promising. This possibility opens the door to the use of types of biomass that until now are mostly outside the biomass supply chains for energy, but which, when introduced, will allow the reduction of production costs with the acquisition of raw materials, ones that do not compete with the circuits already installed to supply industry.

Author Contributions: Conceptualization, L.J.R.N. and A.M.M.M.; methodology, L.J.R.N. and A.M.M.M.; validation, L.C.R.S., L.M.E.F.L., and L.J.R.N.; formal analysis, L.C.R.S., L.M.E.F.L., and L.J.R.N.; investigation, L.C.R.S., L.M.E.F.L., and L.J.R.N.; resources, L.J.R.N.; data curation, L.C.R.S., L.M.E.F.L., and L.J.R.N.; writing-original draft preparation, L.C.R.S. and L.M.E.F.L.; writing-review and editing, L.J.R.N. and A.M.M.M.; supervision, L.J.R.N. and A.M.M.M.; and project administration, L.J.R.N. and A.M.M.M. All authors have read and agreed to the published version of the manuscript.

Funding: This research received no external funding.

Acknowledgments: The authors would like to acknowledge the Portuguese companies YGE (Yser Green Energy SA) and AFS (Advanced Fuel Solutions SA), both in Portugal, who allowed the execution of the laboratory tests.

Conflicts of Interest: The authors declare no conflict of interest.

\section{References}

1. Omer, A.M. Energy, environment and sustainable development. Renew. Sustain. Energy Rev. 2008, 12, 2265-2300. [CrossRef]

2. Renton, A. Suffering the Science: Climate change, people, and poverty. Oxfam Policy Pract. Clim. Chang. Resil. 2009, 5, 53-113.

3. Sheldon, R.A. Green and sustainable manufacture of chemicals from biomass: State of the art. Green Chem. 2014, 16, 950-963. [CrossRef]

4. Zhang, L.; Xu, C.C.; Champagne, P. Overview of recent advances in thermo-chemical conversion of biomass. Energy Convers. Manag. 2010, 51, 969-982. [CrossRef]

5. Demirbas, A. Potential applications of renewable energy sources, biomass combustion problems in boiler power systems and combustion related environmental issues. Prog. Energy Combust. Sci. 2005, 31, 171-192. [CrossRef]

6. Vélez, F.; Segovia, J.J.; Martín, M.C.; Antolín, G.; Chejne, F.; Quijano, A. A technical, economical and market review of organic Rankine cycles for the conversion of low-grade heat for power generation. Renew. Sustain. Energy Rev. 2012, 16, 4175-4189. [CrossRef]

7. Balat, M. Use of biomass sources for energy in Turkey and a view to biomass potential. Biomass Bioenergy 2005, 29, 32-41. [CrossRef]

8. Franco, A.; Giannini, N. Perspectives for the use of biomass as fuel in combined cycle power plants. Int. J. Therm. Sci. 2005, 44, 163-177. [CrossRef]

9. Vassilev, S.V.; Vassileva, C.G.; Vassilev, V.S. Advantages and disadvantages of composition and properties of biomass in comparison with coal: An overview. Fuel 2015, 158, 330-350. [CrossRef] 
10. Maciejewska, A.; Veringa, H.; Sanders, J.; Peteves, S. Co-Firing of Biomass with Coal: Constraints and Role of Biomass Pretreatment; 9279029894; Office for Official Publications of the European Communities: Luxemburg, 2006.

11. Van der Stelt, M.; Gerhauser, H.; Kiel, J.; Ptasinski, K. Biomass upgrading by torrefaction for the production of biofuels: A review. Biomass Bioenergy 2011, 35, 3748-3762. [CrossRef]

12. Nhuchhen, D.R.; Basu, P.; Acharya, B. A comprehensive review on biomass torrefaction. Int. J. Renew. Energy Biofuels 2014, 2014, 1-56. [CrossRef]

13. Klinger, J.; Bar-Ziv, E.; Shonnard, D. Unified kinetic model for torrefaction-pyrolysis. Fuel Process. Technol. 2015, 138, 175-183. [CrossRef]

14. Ciolkosz, D.; Wallace, R. A review of torrefaction for bioenergy feedstock production. Biofuels Bioprod. Biorefining 2011, 5, 317-329. [CrossRef]

15. Acharya, B.; Sule, I.; Dutta, A. A review on advances of torrefaction technologies for biomass processing. Biomass Convers. Biorefinery 2012, 2, 349-369. [CrossRef]

16. Fernandes, U.; Costa, M. Potential of biomass residues for energy production and utilization in a region of Portugal. Biomass Bioenergy 2010, 34, 661-666. [CrossRef]

17. Viana, H.; Cohen, W.B.; Lopes, D.; Aranha, J. Assessment of forest biomass for use as energy. GIS-based analysis of geographical availability and locations of wood-fired power plants in Portugal. Appl. Energy 2010, 87, 2551-2560. [CrossRef]

18. Monteiro, E.; Mantha, V.; Rouboa, A. The feasibility of biomass pellets production in Portugal. Energy Sources Part B Econ. Plan. Policy 2013, 8, 28-34. [CrossRef]

19. Barreiro, S.; Tomé, M. Analysis of the impact of the use of eucalyptus biomass for energy on wood availability for eucalyptus forest in Portugal: A simulation study. Ecol. Soc. 2012, 17, 17. [CrossRef]

20. Lopes, E.; Dias, A.; Arroja, L.; Capela, I.; Pereira, F. Application of life cycle assessment to the Portuguese pulp and paper industry. J. Clean. Prod. 2003, 11, 51-59. [CrossRef]

21. Casanave, D.; Duplan, J.-L.; Freund, E. Diesel fuels from biomass. Pure Appl. Chem. 2007, 79, $2071-2081$. [CrossRef]

22. Toklu, E. Biomass energy potential and utilization in Turkey. Renew. Energy 2017, 107, 235-244. [CrossRef]

23. Demirbas, M.; Balat, M. Recent advances on the production and utilization trends of bio-fuels: A global perspective. Energy Convers. Manag. 2006, 47, 2371-2381. [CrossRef]

24. McKendry, P. Energy production from biomass (part 1): Overview of biomass. Bioresour. Technol. 2002, 83, 37-46. [CrossRef]

25. Hu, L.; Zhao, G.; Hao, W.; Tang, X.; Sun, Y.; Lin, L.; Liu, S. Catalytic conversion of biomass-derived carbohydrates into fuels and chemicals via furanic aldehydes. RSC Adv. 2012, 2, 11184-11206. [CrossRef]

26. Ragauskas, A.J.; Beckham, G.T.; Biddy, M.J.; Chandra, R.; Chen, F.; Davis, M.F.; Davison, B.H.; Dixon, R.A.; Gilna, P.; Keller, M. Lignin valorization: Improving lignin processing in the biorefinery. Science 2014, 344, 1246843. [CrossRef] [PubMed]

27. Yang, H.; Yan, R.; Chen, H.; Zheng, C.; Lee, D.H.; Liang, D.T. In-depth investigation of biomass pyrolysis based on three major components: Hemicellulose, cellulose and lignin. Energy Fuels 2006, 20, 388-393. [CrossRef]

28. Zugenmaier, P. Contribution to the historical development of macromolecular chemistry-Exemplified on cellulose. Cellul. Chem. Technol. 2009, 43, 351.

29. Gilbert, H.J. The biochemistry and structural biology of plant cell wall deconstruction. Plant Physiol. 2010, 153, 444-455. [CrossRef]

30. Hedges, J.I.; Mann, D.C. The characterization of plant tissues by their lignin oxidation products. Geochim. Et Cosmochim. Acta 1979, 43, 1803-1807. [CrossRef]

31. Anwar, Z.; Gulfraz, M.; Irshad, M. Agro-industrial lignocellulosic biomass a key to unlock the future bio-energy: A brief review. J. Radiat. Res. Appl. Sci. 2014, 7, 163-173. [CrossRef]

32. Demirbas, A. Competitive liquid biofuels from biomass. Appl. Energy 2011, 88, 17-28. [CrossRef]

33. Saidur, R.; Abdelaziz, E.; Demirbas, A.; Hossain, M.; Mekhilef, S. A review on biomass as a fuel for boilers. Renew. Sustain. Energy Rev. 2011, 15, 2262-2289. [CrossRef]

34. Jenkins, B.; Baxter, L.; Miles Jr, T.; Miles, T. Combustion properties of biomass. Fuel Process. Technol. 1998, 54, 17-46. [CrossRef] 
35. Yin, C.-Y. Prediction of higher heating values of biomass from proximate and ultimate analyses. Fuel 2011, 90, 1128-1132. [CrossRef]

36. Forbes, E.; Easson, D.; Lyons, G.; McRoberts, W. Physico-chemical characteristics of eight different biomass fuels and comparison of combustion and emission results in a small scale multi-fuel boiler. Energy Convers. Manag. 2014, 87, 1162-1169. [CrossRef]

37. Khaled, H.; Fawy, H.A. Effect of different levels of humic acids on the nutrient content, plant growth, and soil properties under conditions of salinity. Soil Water Res. 2011, 6, 21-29. [CrossRef]

38. Wolf, B. A comprehensive system of leaf analyses and its use for diagnosing crop nutrient status. Commun. Soil Sci. Plant Anal. 1982, 13, 1035-1059. [CrossRef]

39. Uusitalo, M.; Vuoristo, P.; Mäntylä, T. Elevated temperature erosion-corrosion of thermal sprayed coatings in chlorine containing environments. Wear 2002, 252, 586-594. [CrossRef]

40. Kleinert, M.; Barth, T. Towards a lignincellulosic biorefinery: Direct one-step conversion of lignin to hydrogen-enriched biofuel. Energy Fuels 2008, 22, 1371-1379. [CrossRef]

41. Arbon, I. Worldwide use of biomass in power generation and combined heat and power schemes. Proc. Inst. Mech. Eng. Part A J. Power Energy 2002, 216, 41-57. [CrossRef]

42. Toftegaard, M.B.; Brix, J.; Jensen, P.A.; Glarborg, P.; Jensen, A.D. Oxy-fuel combustion of solid fuels. Prog. Energy Combust. Sci. 2010, 36, 581-625. [CrossRef]

43. Werther, J.; Saenger, M.; Hartge, E.-U.; Ogada, T.; Siagi, Z. Combustion of agricultural residues. Prog. Energy Combust. Sci. 2000, 26, 1-27. [CrossRef]

44. Doshi, V.; Vuthaluru, H.B.; Korbee, R.; Kiel, J.H. Development of a modeling approach to predict ash formation during co-firing of coal and biomass. Fuel Process. Technol. 2009, 90, 1148-1156. [CrossRef]

45. Wang, Z.; He, T.; Qin, J.; Wu, J.; Li, J.; Zi, Z.; Liu, G.; Wu, J.; Sun, L. Gasification of biomass with oxygen-enriched air in a pilot scale two-stage gasifier. Fuel 2015, 150, 386-393. [CrossRef]

46. McKendry, P. Energy production from biomass (part 3): Gasification technologies. Bioresour. Technol. 2002, 83, 55-63. [CrossRef]

47. Devi, L.; Ptasinski, K.J.; Janssen, F.J. A review of the primary measures for tar elimination in biomass gasification processes. Biomass Bioenergy 2003, 24, 125-140. [CrossRef]

48. Kim, K.H.; Kim, J.-Y.; Cho, T.-S.; Choi, J.W. Influence of pyrolysis temperature on physicochemical properties of biochar obtained from the fast pyrolysis of pitch pine (Pinus rigida). Bioresour. Technol. 2012, 118, 158-162. [CrossRef]

49. Jahirul, M.I.; Rasul, M.G.; Chowdhury, A.A.; Ashwath, N. Biofuels production through biomass pyrolysis-A technological review. Energies 2012, 5, 4952-5001. [CrossRef]

50. Daugaard, D.E.; Brown, R.C. Enthalpy for pyrolysis for several types of biomass. Energy Fuels 2003, 17, 934-939. [CrossRef]

51. Faaij, A. Modern biomass conversion technologies. Mitig. Adapt. Strateg. Glob. Chang. 2006, 11, $343-375$. [CrossRef]

52. Eseyin, E.; Ekpenyong, I. Advances in Low Temperature Biomass Pyrolysis: A Brief Review. J. Biofuels 2015, $6,44-56$.

53. Shankar Tumuluru, J.; Sokhansanj, S.; Hess, J.R.; Wright, C.T.; Boardman, R.D. A review on biomass torrefaction process and product properties for energy applications. Ind. Biotechnol. 2011, 7, 384-401. [CrossRef]

54. Kwietniewska, E.; Tys, J. Process characteristics, inhibition factors and methane yields of anaerobic digestion process, with particular focus on microalgal biomass fermentation. Renew. Sustain. Energy Rev. 2014, 34, 491-500. [CrossRef]

55. Gunaseelan, V.N. Anaerobic digestion of biomass for methane production: A review. Biomass Bioenergy 1997, 13, 83-114. [CrossRef]

56. Nordin, A.; Pommer, L.; Nordwaeger, M.; Olofsson, I. Biomass conversion through torrefaction. Technol. Convert. Biomass Useful Energy 2013, 217-244. [CrossRef]

57. Azizaddini, S.; Haghparast, A.; Adl, M.; Hadijafari, P. Assessment of gasification potential of agricultural and woody biomass resources. Iran. Int. J. Environ. Bioenergy 2012, 3, 75-87.

58. Li, J.; Brzdekiewicz, A.; Yang, W.; Blasiak, W. Co-firing based on biomass torrefaction in a pulverized coal boiler with aim of 100\% fuel switching. Appl. Energy 2012, 99, 344-354. [CrossRef] 
59. Almeida, G.; Brito, J.O.; Perré, P. Alterations in energy properties of eucalyptus wood and bark subjected to torrefaction: The potential of mass loss as a synthetic indicator. Bioresour. Technol. 2010, 101, 9778-9784. [CrossRef]

60. Sadaka, S.; Negi, S. Improvements of biomass physical and thermochemical characteristics via torrefaction process. Environ. Prog. Sustain. Energy: Off. Publ. Am. Inst. Chem. Eng. 2009, 28, 427-434. [CrossRef]

61. Goldfarb, O. Economic aspects of energy generation using agricultural and municipal solid waste. Ecol. Environ. 2015, 6, 224-230.

62. Proskurina, S.; Heinimö, J.; Schipfer, F.; Vakkilainen, E. Biomass for industrial applications: The role of torrefaction. Renew. Energy 2017, 111, 265-274. [CrossRef]

63. Bergman, P.C.; Kiel, J.H. Torrefaction for biomass upgrading. In Proceedings of the 14th European Biomass Conference, Paris, France, 17 October 2015; pp. 17-21.

64. Medic, D.; Darr, M.; Potter, B.; Shah, A. Effect of torrefaction process parameters on biomass feedstock upgrading. In Proceedings of the 2010 Pittsburgh, Pennsylvania, PA, USA, 20-23 June 2010; p. 1.

65. Wang, L.; Barta-Rajnai, E.; Skreiberg, Ø.; Khalil, R.; Czégény, Z.; Jakab, E.; Barta, Z.; Grønli, M. Impact of torrefaction on woody biomass properties. Energy Procedia 2017, 105, 1149-1154. [CrossRef]

66. Jagodzińska, K.; Czerep, M.; Kudlek, E.; Wnukowski, M.; Pronobis, M.; Yang, W. Torrefaction of agricultural residues: Effect of temperature and residence time on the process products properties. J. Energy Resour. Technol. 2020, 142, 070912. [CrossRef]

67. Silveira, E.A.; Galvão, L.G.O.; Sá, I.A.; Silva, B.F.; Macedo, L.; Rousset, P.; Caldeira-Pires, A. Effect of torrefaction on thermal behavior and fuel properties of Eucalyptus grandis macro-particulates. J. Therm. Anal. Calorim. 2019, 138, 3645-3652. [CrossRef]

68. Kung, K.S.; Shanbhogue, S.; Slocum, A.H.; Ghoniem, A.F. A decentralized biomass torrefaction reactor concept. Part I: Multi-scale analysis and initial experimental validation. Biomass Bioenergy 2019, 125, 196-203. [CrossRef]

69. Kung, K.S.; Ghoniem, A.F. A decentralized biomass torrefaction reactor concept. Part II: Mathematical model and scaling law. Biomass Bioenergy 2019, 125, 204-211. [CrossRef]

70. Nunes, L.J. A Case Study about Biomass Torrefaction on an Industrial Scale: Solutions to Problems Related to Self-Heating, Difficulties in Pelletizing, and Excessive Wear of Production Equipment. Appl. Sci. 2020, 10, 2546. [CrossRef]

71. Bates, R.B.; Ghoniem, A.F. Biomass torrefaction: Modeling of volatile and solid product evolution kinetics. Bioresour. Technol. 2012, 124, 460-469. [CrossRef]

72. Niu, Y.; Lv, Y.; Lei, Y.; Liu, S.; Liang, Y.; Wang, D. Biomass torrefaction: Properties, applications, challenges, and economy. Renew. Sustain. Energy Rev. 2019, 115, 109395. [CrossRef]

73. Hasan, M.; Haseli, Y. An Oxyfuel Combustion-Based Torrefaction Process: Technoeconomic Analysis. J. Energy Resour. Technol. 2020, 142, 032205. [CrossRef]

74. Ribeiro, J.M.C.; Godina, R.; Matias, J.C.d.O.; Nunes, L.J.R. Future perspectives of biomass torrefaction: Review of the current state-of-the-art and research development. Sustainability 2018, 10, 2323. [CrossRef]

75. Rodrigues, A.; Nunes, L. Evaluation of ash composition and deposition tendencies of biomasses and torrefied products from woody and shrubby feedstocks: SRC poplar clones and common broom. Fuel 2020, 269, 117454. [CrossRef]

76. Hagen-Thorn, A.; Stjernquist, I. Micronutrient levels in some temperate European tree species: A comparative field study. Trees 2005, 19, 572-579. [CrossRef]

77. Soetan, K.; Olaiya, C.; Oyewole, O. The importance of mineral elements for humans, domestic animals and plants: A review. Afr. J. Food Sci. 2010, 4, 200-222.

78. Gaur, N.; Flora, G.; Yadav, M.; Tiwari, A. A review with recent advancements on bioremediation-based abolition of heavy metals. Environ. Sci. Process. Impacts 2014, 16, 180-193. [CrossRef]

79. Kamnev, A.A. Phytoremediation of heavy metals: An overview. Recent Adv. Mar. Biotechnol. 2003, 8, $269-318$.

80. Sarmento, P.; Monteiro, G.; Marcelino, F.; Igreja, C.; Caetano, M. Avaliação da Exatidão Temática das Cartas de uso e Ocupação do solo para Portugal Continental COS1995v1.0, COS2007v2.0 e COS2010v1.0. Direção-Geral do Território; DGT: Lisboa, Portugal, 2016.

81. Caldeira, F.; Mestre, S.; Alegria, C.; Quinta-Nova, L.; Albuquerque, M. Os SIG como ferramenta de apoio à gestão sustentável da floresta. In Ii Jorn. Potencial Científico E Técnico Do Ipcb; IPCB: Castelo Branco, Portugal, 2013; pp. 2-10. 
82. Rozefelds, A. Eucalyptus phylogeny and history: A brief summary. Tasforests-Hobart- 1996, 8, 15-26.

83. Águas, A.; Ferreira, A.; Maia, P.; Fernandes, P.M.; Roxo, L.; Keizer, J.; Silva, J.S.; Rego, F.C.; Moreira, F. Natural establishment of Eucalyptus globulus Labill. in burnt stands in Portugal. For. Ecol. Manag. 2014, 323, 47-56. [CrossRef]

84. Mlonka-Mędrala, A.; Gołombek, K.; Buk, P.; Cieślik, E.; Nowak, W. The influence of KCl on biomass ash melting behaviour and high-temperature corrosion of low-alloy steel. Energy 2019, 188, 116062. [CrossRef]

85. Wang, X.; Hu, Z.; Wang, G.; Luo, X.; Ruan, R.; Jin, Q.; Tan, H. Influence of coal co-firing on the particulate matter formation during pulverized biomass combustion. J. Energy Inst. 2019, 92, 450-458. [CrossRef]

86. Vainio, E.; DeMartini, N.; Hupa, L.; Åmand, L.-E.; Richards, T.; Hupa, M. Hygroscopic Properties of Calcium Chloride and Its Role on Cold-End Corrosion in Biomass Combustion. Energy Fuels 2019, 33, 11913-11922. [CrossRef]

87. Meng, X.; Zhou, W.; Rokni, E.; Chen, G.; Sun, R.; Levendis, Y.A. Release of Alkalis and Chlorine from Combustion of Waste Pinewood in a Fixed Bed. Energy Fuels 2019, 33, 1256-1266. [CrossRef]

88. Blomberg, T.; Tripathi, T.; Karppinen, M. New chemical mechanism explaining the breakdown of protective oxides on high temperature steels in biomass combustion and gasification plants. RSC Adv. 2019, 9, 10034-10048. [CrossRef]

89. Uvegi, H.; Chaunsali, P.; Traynor, B.; Olivetti, E. Reactivity of industrial wastes as measured through ICP-OES: A case study on siliceous Indian biomass ash. J. Am. Ceram. Soc. 2019, 102, 7678-7688. [CrossRef]

90. Özsin, G.; Pütün, A.E. TGA/MS/FT-IR study for kinetic evaluation and evolved gas analysis of a biomass/PVC co-pyrolysis process. Energy Convers. Manag. 2019, 182, 143-153. [CrossRef]

91. Rony, A.H.; Kong, L.; Lu, W.; Dejam, M.; Adidharma, H.; Gasem, K.A.; Zheng, Y.; Norton, U.; Fan, M. Kinetics, thermodynamics, and physical characterization of corn stover (Zea mays) for solar biomass pyrolysis potential analysis. Bioresour. Technol. 2019, 284, 466-473. [CrossRef]

92. Brillard, A.; Trouvé, G.; Maryandyshev, P.; Kehrli, D.; Lyubov, V.; Brilhac, J.-F. Analysis through thermogravimetric analyses of the impact of torrefaction processes performed under a non-oxidative atmosphere on hydrolysis lignin samples. Fuel 2020, 260, 116261. [CrossRef]

93. Friedl, A.; Padouvas, E.; Rotter, H.; Varmuza, K. Prediction of heating values of biomass fuel from elemental composition. Anal. Chim. Acta 2005, 544, 191-198. [CrossRef]

94. Grigiante, M.; Antolini, D. Experimental results of mass and energy yield referred to different torrefaction pathways. Waste Biomass Valorization 2014, 5, 11-17. [CrossRef]

95. González-García, S.; Hospido, A.; Moreira, M.T.; Romero, J.; Feijoo, G. Environmental impact assessment of total chlorine free pulp from Eucalyptus globulus in Spain. J. Clean. Prod. 2009, 17, 1010-1016. [CrossRef]

96. Keipi, T.; Tolvanen, H.; Kokko, L.; Raiko, R. The effect of torrefaction on the chlorine content and heating value of eight woody biomass samples. Biomass Bioenergy 2014, 66, 232-239. [CrossRef]

97. Chew, J.J.; Doshi, V. Recent advances in biomass pretreatment-Torrefaction fundamentals and technology. Renew. Sustain. Energy Rev. 2011, 15, 4212-4222. [CrossRef]

(C) 2020 by the authors. Licensee MDPI, Basel, Switzerland. This article is an open access article distributed under the terms and conditions of the Creative Commons Attribution (CC BY) license (http://creativecommons.org/licenses/by/4.0/). 